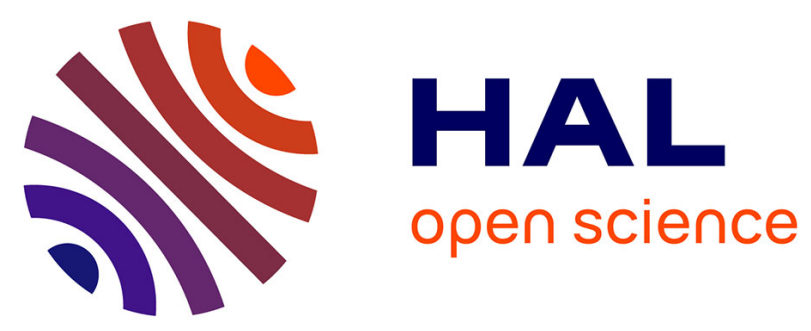

\title{
Chloroquine and Chloroquinoline Derivatives as Models for the Design of Modulators of Amyloid Peptide Precursor Metabolism
}

\author{
Patricia Melnyk, Valérie Vingtdeux, Stéphane Burlet, Sabiha Eddarkaoui, \\ Marie-Eve Grosjean, Paul-Emmanuel Larchanché, Guillaume Hochart, \\ Christian Sergheraert, Cecilia Estrella, Mathieu Barrier, et al.
}

\section{To cite this version:}

Patricia Melnyk, Valérie Vingtdeux, Stéphane Burlet, Sabiha Eddarkaoui, Marie-Eve Grosjean, et al.. Chloroquine and Chloroquinoline Derivatives as Models for the Design of Modulators of Amyloid Peptide Precursor Metabolism. ACS Chemical Neuroscience, 2015, 6 (4), pp.559-569. 10.1021/cn5003013 . hal-02060814

\section{HAL Id: hal-02060814 https://hal.science/hal-02060814}

Submitted on 7 Mar 2019

HAL is a multi-disciplinary open access archive for the deposit and dissemination of scientific research documents, whether they are published or not. The documents may come from teaching and research institutions in France or abroad, or from public or private research centers.
L'archive ouverte pluridisciplinaire HAL, est destinée au dépôt et à la diffusion de documents scientifiques de niveau recherche, publiés ou non, émanant des établissements d'enseignement et de recherche français ou étrangers, des laboratoires publics ou privés. 
ACS Chemical Neuroscience, 2015, 6(4), 559-69. DOI : 10.1021/cn5003013

Highlight in ACS Chemical Research in Toxicology

\title{
Chloroquine and chloroquinoline derivatives as
}

\section{models for the design of modulators of amyloid}

\section{peptide precursor metabolism}

Patricia Melnyk*, ${ }^{*, 2,3}$ Valérie Vingtdeux, ${ }^{1,4}$ Stéphane Burlet, ${ }^{5}$ Sabiha Eddarkaoui, ${ }^{1,4}$ Marie-Eve Grosjean, ${ }^{1,4}$ Paul-Emmanuel Larchanché, ${ }^{1,2}$ Guillaume Hochart, ${ }^{1,2,3}$ Christian Sergheraert, ${ }^{1}$

Cecilia Estrella, ${ }^{5}$ Mathieu Barrier, ${ }^{5}$ Virginie Poix, ${ }^{5}$ Pauline Plancq, ${ }^{5}$ Cécile Lannoo, ${ }^{5}$ Malika Hamdane, ${ }^{1,4}$ André Delacourte, ${ }^{1,4}$ Philippe Verwaerde, ${ }^{5}$ Luc Buée, ${ }^{1,4}$ and Nicolas Sergeant ${ }^{1,4}$

\author{
${ }^{1}$ Université de Lille, F-59000 Lille, France \\ ${ }^{2}$ UDSL, EA 4481, UFR Pharmacie, F-59000 Lille, France \\ ${ }^{3}$ CNRS UMR8161, F-59000 Lille, France \\ ${ }^{4}$ Inserm U837, Jean-Pierre Aubert Research Center, F-59000 Lille, France \\ ${ }^{5}$ AlzProtect, F-59120 Loos, France
}




\section{ABSTRACT}

The amyloid precursor protein (APP) plays a central role in Alzheimer's disease (AD). Preventing deregulated APP processing by inhibiting amyloidogenic processing of carboxy-terminal fragments (APP-CTFs), and reducing the toxic effect of amyloid beta (A $\beta$ ) peptides remain an effective therapeutic strategy. We report the design of piperazine-containing compounds derived from chloroquine structure and evaluation of their effects on APP metabolism and ability to modulate processing of APP-CTF and production of A $\beta$ peptide. Compounds which retained alkaline properties and high affinity for acidic cell compartments were the most effective. The present study demonstrates that (1) the amino side chain of chloroquine can be efficiently substituted by a bis(alkylamino)piperazine chain, (2) the quinoline nucleus can be replaced by a benzyle or a benzimidazole moiety, and (3) pharmacomodulation of the chemical structure allows the redirection of APP metabolism toward a decrease in A $\beta$ peptide release, and increased stability of APP-CTFs and amyloid intracellular fragment. Moreover, the benzimidazole compound 29 increases APP-CTFs in vivo and shows promising activity by the oral route. Together, this family of compounds retains a lysosomotropic activity which inhibits lysosome-related $\mathrm{A} \beta$ production, and is likely to be beneficial for therapeutic applications in AD.

KEY WORDS: Chloroquine, piperazine, Alzheimer's disease, Amyloid Precursor Protein 


\section{INTRODUCTION}

For decades, chloroquine (CQ) has been one of the two most widely used antimalarial drugs with moderate acute toxicity. It is known to cross the BBB. ${ }^{1}$ Following a repositioning strategy, CQ and CQ-derived compounds have already been evaluated in several biological applications such as for prion disease, ${ }^{2-5} \mathrm{HCV}{ }^{6,7}$ and even cancer. ${ }^{8,9}$ Different mechanisms have been proposed for these applications. Unfortunately, the toxicity of CQ precludes its use in long-term treatments. However, CQ-derived compounds such as hydroxychloroquine are administered, for instance, for the treatment of systemic lupus erythematosus ${ }^{10}$ or rheumatoid polyarthritis. ${ }^{11} \mathrm{CQ}$ derivatives may therefore maintain the activity with reduced side effects. For that purpose, we previously developed a library of CQ-derivatives among, from which some compounds demonstrated antimalarial properties and reduced cytotoxic effects upon MRC-5 cells (human diploid embryonic lung cell line). ${ }^{12-14}$ Based on the recent idea that Alzheimer's disease (AD) could be driven by a prion-like spread of protein aggregates in the brain, ${ }^{15,16}$ some compounds of this library have also been positively evaluated for their anti-prion properties. ${ }^{5}$ Recently, we showed that CQ had an indirect modulatory effect on APP metabolism, ${ }^{17}$ the deregulation of which is central to AD pathophysiology. ${ }^{18}$ The role of CQ in AD has also been controversially emphasized by others in the literature. ${ }^{19,20}$

According to the amyloid hypothesis, APP is expected to play a key role in AD. APP metabolism leads to the production and release of amyloid-beta peptides $(A \beta)$, the major component of the amyloid deposits being its 42 aa form. The proteolytic processing of APP brings into play a sequence of cleavages involving either $\alpha$ - or $\beta$-secretase at the first step, followed by $\gamma$-secretase (Figure $\left.1^{16}\right) .{ }^{21}$ The $\alpha$-secretase cleaves APP within the A $\beta$ sequence, producing a soluble fragment $(\operatorname{sAPP} \alpha)$ and a carboxy-terminal fragment $(\mathrm{CTF} \alpha)$, and inhibits $\mathrm{A} \beta$ production. ${ }^{22}$ Through the 
amyloidogenic pathway, $\beta$-secretase cleaves APP at the first amino acid residue of the A $\beta$ sequence, producing a soluble fragment (sAPP $\beta$ ) and a transmembrane carboxy-terminal fragment (CTF $\beta$ ). The APP intracellular domain (AICD) is released by cleavage of CTF $\beta$ at the $\varepsilon$-site by $\gamma$ secretase. ${ }^{23}$ The $\varepsilon$-processed CTF $\beta$ stub is subsequently cleaved at $\gamma$-sites by $\gamma$-secretase to generate A $\beta$ peptides ranging from 46 to 36 amino acids in length, following stepwise successive cleavages along multiple interactive pathways. ${ }^{24-26}$

Current drug candidates for the treatment of amyloid pathology mainly target $\beta$ - or $\gamma$-secretase, in order to avoid the production of $A \beta$ peptides. Most of them have failed, essentially due to low BBB permeability or severe side effects. ${ }^{22}$ Given that the mechanism involved in APP processing is now known to be shared by a growing list of type I transmembrane proteins such as Notch, and that $\beta$ - and $\gamma$-secretase have multiple substrates engaged in ubiquitous cellular and tissue functions, their inhibition may have deleterious effects, and more selective inhibition of APP processing by both proteases is a potential alternative. ${ }^{27,28}$ One way to circumvent these side effects of highly potent $\beta$ - or $\gamma$-secretase inhibitors by using dual inhibitors was recently proposed by Strömberg et $a l .{ }^{29}$ With regards to $\gamma$-secretase, several compounds have been shown (1) to repress or reduce A $\beta$ production, especially A $\beta$ species longer than 40 aa, (2) to maintain AICD release and (3) to spare other $\gamma$-secretase substrates. The so-called $\gamma$-secretase modulators (GSMs) are small molecules demonstrated to act directly on $\gamma$-secretase activity, resulting in a decreased level of long A $\beta$ (140 and 1-42) and an increased level of short $A \beta$ peptides (1-37 and 1-38). We previously showed that CQ inhibits A $\beta$ production, whereas levels of other APP metabolites such as APP-CTFs and AICD are maintained and even increased, and $\gamma$-secretase cleavage of Notch remains unmodified. ${ }^{17,30}$ Thus CQ can be considered as an indirect $\gamma$-secretase modulator since the lysosome is a compartment where $A \beta$ is produced. ${ }^{31}$ 
Here, we have screened our library of CQ-derivatives in order to identify a family of compounds showing an improved effect on APP processing and lower or limited toxicity. ${ }^{12-14}$ Our objective was to identify a compound that can redirect APP metabolism towards the non-amyloidogenic pathway, i.e. that can decrease the level of long A $\beta$ peptides more efficiently than short ones, and increase the level of AICD and SAPP $\alpha$, with a higher efficiency than CQ or other lysosomotropic

compounds. ${ }^{18}$ For that purpose, we first focused on quinoline compounds derived from CQ as the starting point, and increased the ability of compounds to accumulate in acidic vesicles such as lysosomes by adding a bis(alkylamino)piperazine side chain. Secondly, compounds in which the quinoline moiety was replaced by various heterocyclic or aromatic substructures were studied, with an aliphatic amino chain providing the best efficiency. Finally, we evaluated the importance of the symmetry of the compounds (Figure 2). Here, we identified a series of molecules based on a CQ-derived structure, but with a chemically different structure and improved efficiency. Moreover, among those molecules one had low toxicity and provided an interesting in vivo proofof-concept.

\section{RESULTS AND DISCUSSION}

The synthetic pathways of chloroquinoline-piperazine derived compounds, heterocyclic and most benzyl-piperazine derived compounds and symmetric compounds have already been detailed, and compounds $\mathbf{1 - 3 4}, \mathbf{3 7}, \mathbf{3 9}, \mathbf{4 0}, \mathbf{4 2 - 4 7}$ have been described. ${ }^{12-14,32}$ In addition to previously described mono- or dibenzyl derived compounds, fluorobenzyl or thiazolyl compounds $\mathbf{3 5}, \mathbf{3 6}$ and $\mathbf{4 1}$ were easily synthesized by reductive amination according to Scheme 1 .

All compounds were tested for their potential interference with APP processing in an SY5Y human neuroblastoma cell line stably expressing the neuronal isoform of human wild-type APP695 
(SY5Y-APP ${ }^{\mathrm{wt}}$ ), a well-established cellular model for the study of APP metabolism (Figure 3). ${ }^{17,33}$ Thus, to analyze the effect of our compounds on APP metabolism, SY5Y-APP ${ }^{\mathrm{wt}}$ were treated or not with 1 and $5 \mu \mathrm{M}$ of compounds compared to the control condition or to the treatment of SY5Y$\mathrm{APP}^{\mathrm{wt}}$ with 1 or $5 \mu \mathrm{M}$ of $\mathrm{CQ}$ for 6 and 24 hours (Figure 3). Small proteolytic fragments of APP catabolism were resolved by 1D Tris-Tricine gels and detected with our well-characterized APPCterC17 antiserum ${ }^{17,33}$ Identity of APP fragments was previously established by 2D Westernblots. ${ }^{33}$ As shown on Figure 3, all APP fragments including APP-CTFs derived from the $\alpha$ - and $\beta$ cleavages are detected as well as the AICD. The exposure of 5 min enabled to quantify the APPCTFs whilst following 30 min of exposure AICD signal was quantified. Following treatment with 1 or $5 \mu \mathrm{M}$ of compound 33, $\alpha$ - and $\beta$-CTFs amounts were double when compared to CQ treatment (Figure 3, upper Western-blot). AICD production increased fivefold at $5 \mu \mathrm{M}$ of compound 33 following 24 hours of treatment (Figure 3, AICD panel). AICD $\mathrm{C}_{2}$ and $\mathrm{C}_{10}$ indicate the concentrations of compound necessary to double $\left(\mathrm{C}_{2}\right)$ or increase by 10 -fold $\left(\mathrm{C}_{10}\right)$ the quantity of AICDs produced compared with untreated control conditions. These were calculated based on the measure of AICD following a wider range of concentrations.

Cytotoxicity and $A \beta_{1-42}$ levels, determined for all compounds, were defined as critical parameters and were measured using in vitro assays. All values are reported in Tables 1, 2 and 3.

Cytotoxicity is expressed as the compound concentration causing $50 \%$ cell death $\left(\mathrm{CC}_{50}\right)$. $\mathrm{IC}_{50}$ indicates the concentration of compound capable of inhibiting secretion of $\mathrm{A} \beta_{1-42}$ by $50 \%$ (Tables 1-3). For the most potent compounds, CTF $\alpha$, secreted $A \beta_{1-38, A}, \beta_{1-40}$ and sAPP $\alpha$ concentrations were also determined (Table 4). A preliminary ADME (Absorption, Distribution, Metabolism, Excretion) evaluation was performed (Table 5), and finally, the most potent compound was selected for acute in vivo administration by the oral route (Figure 4). 
For the reference compound CQ, the AICD $\mathrm{C}_{2}$ and $\mathrm{C}_{10}$ were $1.4 \mu \mathrm{M}$ and $10.8 \mu \mathrm{M}$ respectively (Table 1). The AICD $\mathrm{C}_{2}$ value of quinacrine $1.0 \mu \mathrm{M}$ was comparable to that of $\mathrm{CQ}$, but its high cytotoxicity to SY5Y-APP ${ }^{\mathrm{wt}}$ cells precluded the evaluation of other parameters. With the exception of compounds $\mathbf{5}$ and $\mathbf{8}$, the AICD $\mathrm{C}_{2}$ values of amide derivatives were comparable to that of $\mathrm{CQ}$ (1-5 $\mu \mathrm{M})$, although AICD $\mathrm{C}_{10}$ values for most compounds were higher than that of CQ (17-40 $\mu \mathrm{M})$. For aromatic amides, substitution was allowed, but the presence of an electron-donating group was probably unfavorable for activity, although the permeability of cells to these compounds was not measured. In the case of aliphatic amides, tert-butyl amide $\mathbf{6}$ displayed the same activity as $\mathrm{CQ}$, whereas the others compounds were less effective. The ability of amides to decrease the amount of secreted $A \beta_{1-42}$ was comparable to that of $C Q$, but slightly improved in the case of aromatic or bulky hydrophobic substituents.

Overall, secondary and tertiary amines (series Ib and Ic) were more effective than their amide counterparts. However, amines were also more toxic with the exception of the cyclopropyl derivative 15. Because of their cytotoxicity to SY5Y-APP ${ }^{\mathrm{wt}}$ cells, as already shown for other cell lines, ${ }^{12}$ the activity of monobenzyl amines 9-11 (except compound 12) and dibenzyl derivatives 17-20 could not be further tested in this assay. The ability of secondary amines to double the amount of AICD fragment was in the same range as for CQ $(1-3 \mu \mathrm{M})$, although the AICD $\mathrm{C}_{10}$ of these compounds was often higher (except for compound 15). We observed that the activity and cytotoxicity on SY5Y-APP ${ }^{\mathrm{wt}}$ cells of amines were highly dependent on their structure. Indeed, steric hindrance might play an important role since the activity of the tert-butyl derivative $\mathbf{1 4}$ was comparable to that of CQ, whereas compound $\mathbf{1 3}$ was less active. In this series, benzyl or tertbutyl substituents favored the decrease of $A \beta_{1-42}$ production. Generally, the activity of tertiary 
amines (series Ic) was higher than that of secondary amines. In tertiary amines, steric hindrance seemed to be important, since substitution with cyclopropylmethyl (compound 23) or isobutyl (compound 24) increased their activity. It was also worth noting the difference between the cyclic amines 25 and 26 in terms of cytotoxicity on SY5Y-APP ${ }^{\mathrm{wt}}$ cells, whereas their influence on AICD production remained comparable, even though the $A \beta_{1-42} \mathrm{IC}_{50}$ was four times higher for the piperidine derivative (1.0 $\mu \mathrm{M}$ for $\mathbf{2 5}$ and $4.0 \mu \mathrm{M}$ for $\mathbf{2 6}$ ).

It is generally accepted that the increased basicity of compounds leads to better uptake by acidic compartments owing to the $\mathrm{pH}$ gradient between the cytosol and the compartment. Using CQ as a starting point, we evaluated derivatives with an increased ability to accumulate in acidic vesicles by adding a bis(alkylamino)piperazine side chain. In Series I, compounds 9-13 and 14-19 were chosen to evaluate the influence of a supplementary basic nitrogen, while compounds $\mathbf{1 - 8}$ could be compared to CQ. The ability of these compounds to accumulate in acidic cell compartments was estimated by calculating a lysosome accumulation ratio (LAR), similar to the antimalarial accumulation ratio in parasite food vacuoles (VAR). LAR could be determined according to Equation $1,{ }^{34}$ based on a weak base model, proceeding from a derivation of the HendersonHasselbach equation in previous work by Hawley et al. ${ }^{35}$ As expected, amides 1-8 displayed an LAR similar to that of CQ $\left(\right.$ LAR $\left.=30-50.10^{3}\right)$ but amines 9-16 and 17-24 showed a 200-fold increase in accumulation $\left(\mathrm{LAR}=56-60.10^{5}\right)$. This seemed to correlate with the comparable activity of amides 1-8 with CQ, whereas tertiary amines showed a greater influence on APP metabolism. Secondary amines, with a higher LAR compared to CQ, also showed a comparable influence on APP metabolism (AICD and $\mathrm{A} \beta_{1-42}$ secretion). It is worth noting that an aliphatic substitution of tertiary amines has little influence on AICD and $A \beta_{1-42}$ secretion (except compound 22), but increases cytotoxicity by around ten times. 
The diisobutylamino side chain was chosen for further studies. We aimed to evaluate the role of the quinoline moiety, as we have previously done for antimalarial activity, ${ }^{13}$ for a family of analogs in which a common $\mathrm{N}_{1}, \mathrm{~N}_{1}$-diisobutyl-1,4-bis(3-aminopropyl) piperazine motif was linked to a variety of aromatic entities.

Two series of compounds: heteroarylamines (compounds 27-32, series IIa) and benzylamines (compounds 33-37, series IIb) were selected in order to simultaneously study the influence of the nature of the chemical link on cytotoxicity, the accumulation of AICDs and the secretion of A $\beta_{1-}$ 42 (Table 2). With regard to the replacement of the quinoline moiety by a heterocycle, benzimidazole was the most efficient in order to maintain an effect on APP metabolism compared to compound 24. An acridine nucleus was selected for comparison with quinacrine but no results could be obtained because of its cytotoxicity. In the case of the benzoxazole ring (compound 28), the compound decreased AICD level at a concentration of $5.0 \mu \mathrm{M}$. Substitution with other heterocycles such as pyrazine (compound 31) led to lower activity, and AICD $\mathrm{C}_{10}$ could not be determined. The influence of the substitution on $A \beta_{1-42}$ peptide secretion could not be measured in any of these cases. In the case of the pyrimidine and purine derivatives (compounds $\mathbf{3 0}$ and $\mathbf{3 2}$ ), no activity at concentrations up to $10 \mu \mathrm{M}$ could be detected, with regard to either AICD fragment production or $\mathrm{A} \beta_{1-42}$ secretion.

The chloroquinoline nucleus could also be replaced by a benzyl moiety, which induced a slight decrease in the production of AICDs and $A \beta_{1-42}$ (Table 2). The ability of methoxy $\mathbf{3 3}$, chloro $\mathbf{3 4}$ or fluoro 35 derivatives to double or increase 10-fold the quantity of AICD fragments generated was in the same range as $\mathrm{CQ}\left(\mathrm{C}_{2}=1-3 \mu \mathrm{M}\right.$ and $\left.\mathrm{C}_{10}=10-16 \mu \mathrm{M}\right)$. On the other hand, the nature of the substituent on the phenyl ring modified the quantity of secreted $A \beta_{1-42}$, resulting in a comparable $\mathrm{IC}_{50}$ for compounds $\mathbf{3 3}$ and $\mathbf{3 4}$, whereas compound $\mathbf{3 5}$ did not induce a decrease in 
$\mathrm{A} \beta_{1-42}$ secretion at $5 \mu \mathrm{M}$. Conversely, compound 37, with a pyridine ring, was found to be slightly less active in terms of AICD production than the phenyl compounds, but no effect could be detected on secreted $A \beta_{1-42}$ at concentrations below $5 \mu \mathrm{M}$. Surprisingly, when the phenyl ring was replaced by a thiazole ring (compound 36), no effect was observed on the secretion of $A \beta_{1-42}$, and AICD production was shown to decrease at concentrations below $5 \mu \mathrm{M}$, in contrast to the other compounds of this series.

Finally, we evaluated the influence of compound symmetry (Table 3) using alkyl- or benzyl-type substituents. Except in the case of derivatives 44, 45 and 46, all the compounds showed higher cytotoxicity on SY5Y-APP ${ }^{\mathrm{wt}}$ cells than previous series, making it difficult to evaluate their activity in this cellular model. Commercially available unsubstituted diamine, 38, had no influence on AICD levels or secreted $A \beta_{1-42}$. With benzyl substituents, at the non-cytotoxic concentration of 5 $\mu \mathrm{M}$, an increase in $\mathrm{A} \beta$ secretion was observed without affecting AICD levels. Surprisingly, $p$ chlorobenzyl derivative $\mathbf{4 0}$ behaved differently and was one of the most effective compounds both with regard to the production of $\operatorname{AICD}\left(\mathrm{C}_{2}=0.5 \mu \mathrm{M}\right)$ and the secretion of $\mathrm{A} \beta_{1-42}\left(\mathrm{IC}_{50}=3.1 \mu \mathrm{M}\right)$, as seen for Series II. For the dialkyl compounds $\mathbf{4 5}$ and $\mathbf{4 6}$, a significant increase in $\mathrm{A} \beta_{1-42}$ secretion was measured, with little impact on AICD levels. In contrast, the tetra-isobutyl compound 47 showed a comparable impact to CQ on APP metabolism $\left(\mathrm{C}_{2}=3.7 \mu \mathrm{M}\right.$ for $47,1.4 \mu \mathrm{M}$ for $\left.\mathrm{CQ}\right)$, but no influence on the secretion of $A \beta_{1-42}$ at the concentration of $5 \mu \mathrm{M}$.

The influence on accumulation in acidic compartments in this series did not seem to be critical, since compounds with a comparable theoretical LAR showed widely differing effects on APP metabolism. For instance, with similar LAR values of $15.10^{6}$, the presence of a $p$-fluorobenzyl group (compound 35), increased the secretion of $A \beta_{1-42}$, but did not significantly modify AICD levels compared to a $p$-methoxy or $p$-chlorobenzyl group (compounds $\mathbf{3 3}$ and $\mathbf{3 4}$ ). In this series, 
most compounds did not modify the secretion of $A \beta_{1-42}$ at concentrations below $5 \mu \mathrm{M}$. In the case of symmetric compounds (Series 3), except for bis(p-chlorobenzyl) or bis(diisobutyl) compounds 40 and 47, no influence on the quantity of AICD could be measured, but these compounds led to an increase in the secretion of $A \beta_{1-42}$ at concentrations below $5 \mu \mathrm{M}$. Once again, the ability to be accumulated in lysosomes/endosomes could not be considered, since the calculated LARs were comparable $\left(\mathrm{LAR}=15 \cdot 10^{6}\right)$. Thus, LAR values do not seem to be highly relevant or even the only criteria in explaining the relative influence of these compounds on APP metabolism compared to CQ.

Given the interest of quinoline 25, benzimidazole 29 and benzyle 33 compounds demonstrated above, further experiments were designed to evaluate their impact on the metabolism of APP in greater detail. The neurotrophic fragments sAPP $\alpha$ and CTF $\alpha^{36}$, as well as the shorter $\mathrm{A} \beta_{1-38}$ and $A \beta_{1-40}$ peptides, were quantified (Table 4). The closest analogs of CQ 25 and benzimidazole 29 showed the greatest effects on APP metabolism, with a CTF $\alpha \mathrm{C}_{2}$ value of 0.2 and $0.5 \mu \mathrm{M}$ respectively and a CTF $\alpha \mathrm{C}_{10}$ close to $10 \mu \mathrm{M}$. Substitution with a methoxybenzyle moiety decreased the production of CTF $\alpha\left(\mathrm{C}_{2}=6.7 \mu \mathrm{M}\right.$ and $\left.\mathrm{C}_{10}=28.4 \mu \mathrm{M}\right)$. Surprisingly, the levels of CTF $\alpha$ and sAPP $\alpha$ seemed uncorrelated for compound 25. At a concentration of $10 \mu \mathrm{M}$, which increased the quantity of CTF $\alpha$ produced ten times, sAPP $\alpha$ was only increased by $30 \%$. At this concentration, sAPP $\alpha$ was increased by $78 \%$ for benzimidazole 29 and $55 \%$ for methoxybenzyle compound $\mathbf{3 3}$. Since the ability of the three compounds $\mathbf{2 5}, \mathbf{2 9}$ and $\mathbf{3 3}$ to decrease the secretion of $\mathrm{A} \beta_{1-42}$ was equivalent ( $\mathrm{IC}_{50}$ close to $1 \mu \mathrm{M}$ ), benzimidazole 29 appeared more effective with regard to $\mathrm{A} \beta_{1-40}$, with an $\mathrm{IC}_{50}$ of $2.0 \mu \mathrm{M}$, compared to $\mathbf{3 3}$, with a value of $5.1 \mu \mathrm{M}$ and $\mathbf{2 5}$, with a value of $9.1 \mu \mathrm{M}$. Interestingly, the influence of these compounds on the secretion of the short $A \beta_{1-38}$ peptide was 
also very different, as the $\mathrm{IC}_{50}$ was $5.0 \mu \mathrm{M}$ for compounds $\mathbf{2 5}$ and $\mathbf{2 9}$, whereas compound $\mathbf{3 3}$ seemed to be inactive at concentrations up to $10 \mu \mathrm{M}$. These two compounds were also able to inhibit the secretion of $A \beta_{1-38}$ and $A \beta_{1-40}$ more effectively. The activity of these three compounds on the metabolism of APP was also confirmed by measuring the secretion of $\operatorname{sAPP} \alpha$, a fragment previously described as being neuroprotective. ${ }^{36}$

The mechanism of action of these compounds had to be deciphered. Starting from CQ, the introduction of a polyamino side chain should have led to more efficient accumulation in acidic vacuoles. Interestingly, however, when evaluated as antimalarials, these compounds were shown not to accumulate in parasite food vacuoles. ${ }^{37}$ With respect to their influence on the secretion of $A \beta$ peptides of different lengths, the three compounds of interest seemed to have different or complementary mechanisms of action, especially with regard to LAR values. However, a lysosomotropic activity of these compounds cannot be ruled-out. Regarding the possible effect of AICD, whether as a transcriptional gene regulator or a toxic effect, the AICD must reach the cell nucleus. The transcriptional active AICD is supposed to originate from the $\beta$-CTF. ${ }^{38}$ This mechanism supposes that a $\gamma$-secretase cleavage of the $\beta$-CTF occurs rapidly along the early endosome / lysosome pathway. AICD can also be produced later in the endosome / lysosome route and being degraded by lysosome proteases ${ }^{39}$ or secreted in the extracellular space via exosomes ${ }^{17}$. Consistent with this mechanism, accumulating evidences suggest that $40 \%$ of APP metabolism occurs in the late endosome / lysosome pathway. ${ }^{31,40}$ Cyclopamine reduces the $\mathrm{A} \beta$ production and redirect part of the APP processing to the lysosome compartment ${ }^{40}$ giving similar results to that obtain with our small compounds. This effect does not imply a modulation of the gamma-secretase activity. We also tested the in vitro $\gamma$-secretase activity as well as the $\gamma$-secretase processing of Notch (unpublished data). Both are not modified by our compounds. Interestingly, a nuclear 
accumulation of AICD was not reported in these studies further supporting the hypothesis that AICD can be produce along the endosome / lysosome pathway giving rise to a transcriptionally active fragment when produced in early endosomal route or alternatively, AICD can also be produced in late endosome compartments such as multivesicular bodies. ${ }^{17}$ Absence of nuclear signal is not due to our APP-CterC17 antibody since our antibody used to visualize the nuclear localization of AICD. ${ }^{41}$ Taken together, our past and current results strongly suggest that AICD accumulation is related to a modification of the late endosome /lysosome processing of AICD and would therefore explain why a toxic effect of the accumulation of AICD is not herein observed whereas nuclear AICD signaling is reported to be toxic. ${ }^{42-44}$ Hence, in sharp contrast to cyclopamine, which is a highly teratogen drug, one of our lead compound has passed the preclinical phase and is currently in clinical phase I. However, further investigation should be done to decipher the precise molecular mechanism of action of our compounds.

Some preliminary ADME parameters were evaluated before an in vivo evaluation (Table 5). The three compounds were highly soluble in water $(>200 \mu \mathrm{M}$ at $\mathrm{pH} 7.4)$ but showed different $\log \mathrm{D}$ values, with a very low value of 0.1 for quinoline $\mathbf{2 5}$, predicting a low probability of BBB penetration. In contrast, benzimidazole $\mathbf{2 9}$ and compound $\mathbf{3 3}$ displayed intermediate values of 1.8 and 1.2, respectively. Evaluation of metabolic stability using mouse and human liver microsomes showed high stability for compound 25 (100\% of the compound remaining after $1 \mathrm{~h})$ and benzimidazole 29 (79 and 52\% of the compound remaining after $1 \mathrm{~h}$ ). In contrast, compound 33 showed low stability (30\% and 27\% after 1 h). Compounds $\mathbf{2 5}$ and $\mathbf{3 3}$ were not evaluated in this study for an in vivo proof-of-concept. 
Finally, to determine the modulatory effects of our compounds on APP metabolism in vivo, a single dose treatment was carried out in wild-type C57Bl6 mice (Figure 4). Physiologically, AICDs were rarely detected and assumed to be rapidly degraded. After a single administration of compound $\mathbf{2 9}$ by the oral route, mice were sacrificed $24 \mathrm{~h}$ later and quantification by western blotting highlighted a significant increase in CTF $\alpha$ level. A single dose of compound 29 led to an increase in CTF $\alpha$ in the frontal cortex from a $5 \mathrm{mg} / \mathrm{kg}$ dose, and in the hippocampus from a $12.5 \mathrm{mg} / \mathrm{kg}$ dose. A $25 \mathrm{mg} / \mathrm{kg}$ dose was the most efficient and significant, with an increase of CTF $\alpha$ of $29 \%$ in the frontal cortex and $20 \%$ in the hippocampus. This first in vivo proof-of-concept should be confirmed by further long-term administration studies of compound $\mathbf{2 9}$.

\section{CONCLUSION}

Previous studies have underlined the interest of CQ and alkaline drugs as AICD enhancers and compounds capable of interacting with the endosome/lysosome pathway, a mechanism that is of growing interest in neurodegenerative diseases including AD. The present study of several series of compounds showed that (1) the chemical structure of CQ could be efficiently modified by adding a bis(alkylamino)piperazine chain, (2) the quinoline nucleus could be replaced by a benzyle or benzimidazole moiety, and (3) pharmacomodulation of the chemical structure allowed the metabolism of APP to be directed toward the decrease of A $\beta$ peptide secretion or the increase of APP-CTF fragments as well as the accumulation of AICDs. Among the compounds evaluated in this study, compounds $\mathbf{2 5 ,} 29$ and $\mathbf{3 3}$ showed a better in vitro profile than CQ on the metabolism of APP. Preliminary ADME and in vivo evaluation underlined the possibility that compound $\mathbf{2 9}$ could find therapeutic applications in neurodegenerative diseases in which APP metabolism needs to be modulated. Thus benzimidazole $\mathbf{2 9}$ is currently under development as a potential anti- 
Alzheimer drug candidate. From a more fundamental point of view, as the most potent molecules were structurally different from CQ, this raises the question of the mechanism of action as well as the potential specific biological targets of this family of molecules.

\section{METHODS}

\section{Chemistry}

Compounds 1-34, 37-40 and 42-47 have already been described and were used at a purity of $>$ 95\%. ${ }^{12-14}$ Chemicals and solvents were obtained from commercial sources, and used without further purification unless otherwise detailed. Reactions were monitored by TLC performed on Macherey-Nagel Alugram ${ }^{\circledR}$ Sil $60 / \mathrm{UV}_{254}$ sheets (thickness $0.2 \mathrm{~mm}$ ). Purification of products was carried out by either column chromatography or thick layer chromatography. Column chromatography was carried out on using Macherey-Nagel silica gel (230-400 mesh). Thick layer chromatography was performed on glass plates coated with Macherey-Nagel Sil/UV 254 (thickness $2 \mathrm{~mm}$ ), from which the pure compounds were extracted with the following solvent system:

$\mathrm{DCM} / \mathrm{MeOH}\left(\mathrm{NH}_{3}\right), 90: 10 .{ }^{1} \mathrm{H}$ and ${ }^{13} \mathrm{C}$ NMR spectra were obtained using a Bruker $300 \mathrm{MHz}$ spectrometer, chemical shifts $(\delta)$ were expressed in ppm relative to TMS used as an internal standard. The attributions of the carbons were deduced after 2D experiments had been performed (COSY, HSQC and HMBC). Mass spectra were recorded on a Varian triple quadrupole $1200 \mathrm{~W}$ mass spectrometer equipped with a non-polar C18 TSK-gel Super ODS (4.6 x $50 \mathrm{~mm})$ column, using electrospray ionization and a UV detector (diode array). The purity of final compounds was verified by two types of high pressure liquid chromatography (HPLC) columns: C18 Deltapak (C18N) and C4 Interchrom UP5WC4-25QS (C4). Analytical HPLC was performed on a Shimadzu system equipped with a UV detector set at $254 \mathrm{~nm}$. Compounds were dissolved in buffer B or 
$\mathrm{MeOH}$ and injected through a $50 \mu \mathrm{L}$ loop. The following eluent systems were used: buffer A $\left(\mathrm{H}_{2} \mathrm{O} / \mathrm{TFA}, 100: 0.05\right)$ and buffer $\mathrm{B}\left(\mathrm{CH}_{3} \mathrm{CN} / \mathrm{H}_{2} \mathrm{O} / \mathrm{TFA}, 80: 20: 0.05\right)$. HPLC retention times (HPLC $t_{R}$ ) were obtained, at flow rates of $1 \mathrm{~mL} / \mathrm{min}$, using the following conditions: for the $10 \mathrm{~min}$ method: a gradient run from 100\% eluent A for 30 s, then to $100 \%$ eluent B for the next 8 min; and for the 40 min method: a gradient run from $100 \%$ eluent A for $1 \mathrm{~min}$, then to $100 \%$ eluent $\mathrm{B}$ for the next $30 \mathrm{~min}$.

\section{(3-\{4-[3-(4-Fluorobenzylamino)propyl]piperazin-1-yl\}propyl)diisobutylamine (35)}

A $3 \AA$ molecular sieve $(1 \mathrm{~g})$ was added to a solution of \{3-[4-(3-aminopropyl)piperazin-1yl]propyl $\}$ diisobutylamine ${ }^{12}(150 \mathrm{mg}, 0.48 \mathrm{mmol})$ and 4-fluorobenzaldehyde $(57 \mu \mathrm{L}, 0.53 \mathrm{mmol})$ in ethanol $(6 \mathrm{~mL})$. The reaction medium was stirred at $20^{\circ} \mathrm{C}$ for $5 \mathrm{~h}$ and cooled to $0^{\circ} \mathrm{C}$. $\mathrm{NaBH}_{4}$ (45.4 mg, $1.2 \mathrm{mmol}$ ) was added portionwise over $15 \mathrm{~min}$, and the reaction medium stirred at $20^{\circ} \mathrm{C}$ for $12 \mathrm{~h}$. The mixture was filtered over Celite. The solvent was removed under reduced pressure and $20 \mathrm{~mL}$ water added to the residue. The product was extracted with dichloromethane, and washed with aqueous $\mathrm{HCl} 1 \mathrm{M}$. The combined organic fractions were washed with water and dried over sodium sulfate. The solvent was evaporated under reduced pressure. Purification by thick layer chromatography (DCM:MeOH:NH$\left.{ }_{4} \mathrm{OH}, 90: 10: 1\right)$ was performed and enabled collection of the product as a yellow solid (102 $\mathrm{mg}, 50 \%) .{ }^{1} \mathrm{H}$ NMR $\left(300 \mathrm{MHz}, \mathrm{CDCl}_{3}\right) \delta 7.20\left(\mathrm{dd},{ }^{3} \mathrm{~J}=8.7\right.$ $\left.\mathrm{Hz},{ }^{4} J_{F}=5.5 \mathrm{~Hz}, 2 \mathrm{H}, \mathrm{H}_{\text {aro }}\right), 6.93\left(\mathrm{~m},{ }^{3} J={ }^{3} J_{F}=8.7 \mathrm{~Hz}, 2 \mathrm{H}, \mathrm{H}_{\text {aro }}\right), 3.67\left(\mathrm{~s}, 2 \mathrm{H}, \mathrm{NHCH}_{2}\right), 2.59\left(\mathrm{t},{ }^{3} J\right.$ $\left.=6.8 \mathrm{~Hz}, 2 \mathrm{H}, \mathrm{NH}-\mathrm{CH}_{2}\right), 2.5-2.2\left(\mathrm{~m}, 14 \mathrm{H}, \mathrm{N}-\mathrm{CH}_{2}\right), 1.96\left(\mathrm{~d},{ }^{3} \mathrm{~J}=7.2 \mathrm{~Hz}, 4 \mathrm{H}, 2 \mathrm{~N}-\mathrm{CH}_{2}\right), 1.68(\mathrm{~m}$, $2 \mathrm{H}, 2 \mathrm{CH}), 1.5-1.4\left(\mathrm{~m}, 4 \mathrm{H}, 2 \mathrm{CH}_{2}\right), 0.78\left(\mathrm{~d},{ }^{3} \mathrm{~J}=6.6 \mathrm{~Hz}, 12 \mathrm{H}, 4 \mathrm{CH}_{3}\right) .{ }^{13} \mathrm{C} \mathrm{NMR}\left(75 \mathrm{MHz}, \mathrm{CD}_{3} \mathrm{OD}\right)$ $\delta 129.8\left(2 \mathrm{CH}_{\text {aro }}\right), 115.1\left(2 \mathrm{CH}_{\text {aro }}\right), 64.1\left(2 \mathrm{NCH}_{2}\right), 57.2\left(\mathrm{NCH}_{2}\right), 57.0\left(2 \mathrm{NCH}_{2}\right), 53.5\left(\mathrm{NHCH}_{2}\right)$, $53.4\left(2 \mathrm{NCH}_{2}\right), 48.3\left(\mathrm{NHCH}_{2}\right), 26.7(2 \mathrm{CH}), 24.6\left(2 \mathrm{CH}_{2}\right), 21.1\left(4 \mathrm{CH}_{3}\right)$. LCMS (ESI $\left.{ }^{+}\right)$: Calc. for 
$[\mathrm{M}+\mathrm{H}]^{+}:$421.36; Found: 421.47. HPLC $\left(\mathrm{C}_{4}, 35 \mathrm{~min}\right): \mathrm{t}_{\mathrm{R}} 6.7 \mathrm{~min}, \mathrm{P}_{\mathrm{HPLC}} 99 \%$; HPLC $\left(\mathrm{C}_{18}, 35 \mathrm{~min}\right)$ : $t_{\mathrm{R}} 3.8 \mathrm{~min}, \mathrm{P}_{\mathrm{HPLC}}>99 \%$.

Diisobutyl-[3-(4-\{3-[(thiazol-2-ylmethyl)amino]propyl\}piperazin-1-yl)propyl]amine (36)

A $3 \AA ̊$ molecular sieve (1 g) was added to a solution of \{3-[4-(3-aminopropyl)piperazin-1yl]propyl $\}$ diisobutylamine ${ }^{12}(150 \mathrm{mg}, 0.48 \mathrm{mmol})$ and 2-thiazolecarboxaldehyde $(46.4 \mu \mathrm{L}, 0.53$ mmol) in ethanol $(6 \mathrm{~mL})$. The reaction medium was stirred at $20^{\circ} \mathrm{C}$ for $5 \mathrm{~h}$ and cooled to $0^{\circ} \mathrm{C}$. $\mathrm{NaBH}_{4}(45.4 \mathrm{mg}, 1.2 \mathrm{mmol})$ was added portionwise over $15 \mathrm{~min}$ and the reaction medium was stirred at $20^{\circ} \mathrm{C}$ for $12 \mathrm{~h}$. The mixture was filtered over Celite. The solvent was removed under reduced pressure and $20 \mathrm{~mL}$ water added to the residue. The product was extracted with dichloromethane, and washed with aqueous $\mathrm{HCl} 1 \mathrm{M}$. The combined organic fractions were washed with water and dried over sodium sulfate. The solvent was evaporated under reduced pressure. Purification by thick layer chromatography (AcOEt:MeOH:NH $4 \mathrm{NH}_{4} \mathrm{OH}$ 90:10:2) was performed and enabled collection of the product as a yellow oil $(69 \mathrm{mg}, 35 \%) .{ }^{1} \mathrm{H} \mathrm{NMR}\left(300 \mathrm{MHz}, \mathrm{CDCl}_{3}\right) \delta 7.66$ $\left(\mathrm{d},{ }^{3} J=3.4 \mathrm{~Hz}, 1 \mathrm{H}, \mathrm{H}_{\text {aro }}\right), 7.20\left(\mathrm{~d},{ }^{3} J=3.4 \mathrm{~Hz}, 1 \mathrm{H}, \mathrm{H}_{\text {aro }}\right), 4.07\left(\mathrm{~s}, 2 \mathrm{H}, \mathrm{NHCH}_{2}\right), 2.70\left(\mathrm{t},{ }^{3} J=6.7\right.$ $\left.\mathrm{Hz}, 2 \mathrm{H}, \mathrm{NH}-\mathrm{CH}_{2}\right), 2.5-2.3\left(\mathrm{~m}, 14 \mathrm{H}, \mathrm{N}-\mathrm{CH}_{2}\right), 1.97\left(\mathrm{~d},{ }^{3} \mathrm{~J}=7.2 \mathrm{~Hz}, 4 \mathrm{H}, 2 \mathrm{~N}-\mathrm{CH}_{2}\right), 1.7-1.5(\mathrm{~m}, 6 \mathrm{H}$, $\left.2 \mathrm{CH}, 2 \mathrm{CH}_{2}\right), 0.79\left(\mathrm{~d},{ }^{3} J=6.5 \mathrm{~Hz}, 12 \mathrm{H}, 4 \mathrm{CH}_{3}\right) .{ }^{13} \mathrm{C} \mathrm{NMR}\left(75 \mathrm{MHz}, \mathrm{CD}_{3} \mathrm{OD}\right) \delta 142.6\left(\mathrm{CH}_{\text {aro }}\right)$, $118.9\left(\mathrm{CH}_{\text {aro }}\right), 64.1\left(2 \mathrm{NCH}_{2}\right), 57.0\left(2 \mathrm{NCH}_{2}\right), 53.4\left(3 \mathrm{NHCH}_{2}\right), 51.2\left(\mathrm{NHCH}_{2}\right), 48.5\left(\mathrm{NHCH}_{2}\right)$, $27.1\left(\mathrm{CH}_{2}\right), 26.7(2 \mathrm{CH}), 24.6\left(\mathrm{CH}_{2}\right), 21.1\left(4 \mathrm{CH}_{3}\right) . \mathrm{LCMS}\left(\mathrm{ESI}^{+}\right)$: Calc. for $[\mathrm{M}+\mathrm{H}]^{+}$: 410.32; Found: 410.40. HPLC ( $\left.\mathrm{C}_{4}, 40 \mathrm{~min}\right): \mathrm{t}_{\mathrm{R}} 3.8 \mathrm{~min}, \mathrm{P}_{\mathrm{HPLC}} 99 \%$; $\mathrm{HPLC}\left(\mathrm{C}_{18}, 35 \mathrm{~min}\right): \mathrm{t}_{\mathrm{R}} 3.8 \mathrm{~min}, \mathrm{P}_{\mathrm{HPLC}}$ $99 \%$.

(4-Fluorobenzyl)-(3-\{4-[3-(4-fluorobenzylamino)propyl]piperazin-1-yl\}propyl)amine (41) 
A $3 \AA ̊$ molecular sieve (5 g) was added to a solution of 1,4-bis(3-aminopropyl)piperazine (515 $\mu \mathrm{L}$, $2.50 \mathrm{mmol})$ and 4-fluorobenzaldehyde $(590 \mu \mathrm{L}, 5.50 \mathrm{mmol})$ in ethanol $(20 \mathrm{~mL})$. The reaction medium was stirred at $20^{\circ} \mathrm{C}$ for $5 \mathrm{~h}$ and cooled to $0^{\circ} \mathrm{C}$. $\mathrm{NaBH}_{4}(0.473 \mathrm{~g}, 12.50 \mathrm{mmol})$ was added portionwise over $15 \mathrm{~min}$ and the reaction medium was stirred at $20^{\circ} \mathrm{C}$ for $12 \mathrm{~h}$. The mixture was filtered over Celite. The solvent was removed under reduced pressure and $20 \mathrm{~mL}$ water added to the residue. The product was extracted with dichloromethane, washed with aqueous $\mathrm{HCl} 1 \mathrm{M}$. The combined organic fractions were washed with water and dried over sodium sulfate. The solvent was evaporated under reduced pressure. Purification by thick layer chromatography (acetone: $\mathrm{NH}_{4} \mathrm{OH}, 90: 10$ ) was performed and enabled collection of the product as a yellow solid $(0.18 \mathrm{~g}, 17 \%) .{ }^{1} \mathrm{H}$ NMR $\left(300 \mathrm{MHz}, \mathrm{CDCl}_{3}\right) \delta 7.21\left(\mathrm{dd},{ }^{3} J=8.7 \mathrm{~Hz},{ }^{4} J=5.5 \mathrm{~Hz}, 4 \mathrm{H}, \mathrm{H}_{\text {aro }}\right), 6.93$ (m, 4H, $\mathrm{H}_{\text {aro }}$ ), $3.68\left(\mathrm{~s}, 4 \mathrm{H}, \mathrm{NHCH}_{2}\right), 2.60\left(\mathrm{t},{ }^{3} \mathrm{~J}=6.8 \mathrm{~Hz}, 4 \mathrm{H}, \mathrm{NH}-\mathrm{CH}_{2}\right), 2.4-2.3\left(\mathrm{~m}, 12 \mathrm{H}, \mathrm{N}-\mathrm{CH}_{2}\right)$, 1.63 (quint, $\left.{ }^{3} J=7.0 \mathrm{~Hz}, 4 \mathrm{H}, \mathrm{CH}_{2}\right) .{ }^{13} \mathrm{C} \mathrm{NMR}\left(75 \mathrm{MHz}, \mathrm{CD}_{3} \mathrm{OD}\right) \delta 129.8\left(\mathrm{CH}_{\text {aro }}\right), 115.5\left(\mathrm{CH}_{\text {aro }}\right)$, 57.2 $\left(\mathrm{NCH}_{2}\right), 53.4\left(2 \mathrm{NCH}_{2}\right), 53.3\left(\mathrm{NHCH}_{2}\right), 48.3\left(\mathrm{NHCH}_{2}\right), 26.8\left(\mathrm{CH}_{2}\right)$. LCMS (ESI $\left.{ }^{+}\right)$: Calc. for $[\mathrm{M}+\mathrm{H}]^{+}:$: 417.27; Found: 417.04. HPLC $\left(\mathrm{C}_{4}, 40 \mathrm{~min}\right): \mathrm{t}_{\mathrm{R}} 5.9 \mathrm{~min}, \mathrm{P}_{\mathrm{HPLC}}>99 \% ; \mathrm{HPLC}\left(\mathrm{C}_{18}, 35\right.$ $\min ): t_{\mathrm{R}} 3.2 \mathrm{~min}, \mathrm{P}_{\mathrm{HPLC}} 95 \%$.

\section{Cell culture and treatment}

The human neuroblastoma cell line SKNSH-SYSY (SY5Y) was cultured in Dulbecco's modified Eagle medium supplemented with 10\% fetal calf serum (PAA), 2 mM L-glutamine (Invitrogen), $1 \mathrm{mM}$ non-essential amino-acids and penicillin/streptomycin (Invitrogen), in a 5\% $\mathrm{CO}_{2}$ humidified incubator at $37^{\circ} \mathrm{C}$. The human APP695 cDNA was subcloned into eukaryotic expression vector pcDNA3.1 (Invitrogen), allowing for G418 antibiotic selection of stable clones. This APP cDNA was transfected into SY5Y cells using the ethyleneimine polymer ExGen 500 (Euromedex) 
according to the manufacturer's instructions. SY5Y cells stably expressing the APP695 were selected with Geneticin G418 (Invitrogen) and one clone named SY5Y-APP ${ }^{\mathrm{wt}}$ was used here.

For treatment, SY5Y-APP ${ }^{\mathrm{wt}}$ cells were plated onto 12-well plates (Falcon) $24 \mathrm{~h}$ before drug exposure, and cultured in Dulbecco's modified Eagle medium (Invitrogen) supplemented with 10\% fetal calf serum (PAA), $2 \mathrm{mM}$ L-glutamine (Invitrogen), $1 \mathrm{mM}$ non-essential amino acids (Invitrogen), 50 units/mL penicillin/streptomycin (Invitrogen), and $200 \mu \mathrm{g}$ Geneticin G418 (Invitrogen), under $5 \% \mathrm{CO}_{2}$ at $37^{\circ} \mathrm{C}$. Cells were exposed to drugs at the indicated concentrations for $24 \mathrm{~h}$. After treatment, the conditioned medium was collected, spun at 200xg to eliminate the cell debris and frozen at $-80^{\circ} \mathrm{C}$ for $\mathrm{A} \beta_{1-42}, \mathrm{~A} \beta_{1-40}$ and sAPP $\alpha$ quantification. Treated SY5Y-APP ${ }^{\mathrm{wt}}$ cells were collected in $50 \mu \mathrm{l}$ of Laemmli lysis buffer containing protease inhibitors (Complete Mini, Roche Molecular Biochemicals, Meylan, France), sonicated for 5 min and stored at $-80^{\circ} \mathrm{C}$ until use. Total protein quantification of extracted samples was performed by $\mathrm{BCA}^{\mathrm{TM}}$ Protein Assay Kit (Thermo Scientific) according to the manufacturer's protocol.

\section{Cytotoxicity}

SY5Y-APP ${ }^{\mathrm{wt}}$ cells cultured as described previously were seeded onto 96-well plates and incubated with the compound at $0.1 ; 0.3 ; 1 ; 3 ; 10 ; 30$ and $100 \mu \mathrm{M}$, or DMSO, diluted in the same culture medium as a control, at $37^{\circ} \mathrm{C}$ in $5 \% \mathrm{CO}_{2}$ for $24 \mathrm{~h}(\mathrm{n}=3)$. Cytotoxicity was determined by using colorimetric MTS assay (CellTiter 96® Aqueous One Solution Cell Proliferation Assay-MTS Promega) according to the manufacturer's protocol. Absorbance was read at $490 \mathrm{~nm}$ and cytotoxicity was interpreted as the compound concentration causing $50 \%$ of cell death $\left(\mathrm{CC}_{50}\right)$. Results are shown as a percentage of control conditions which was considered as $100 \%$. 


\section{Western blot analysis}

Samples were heated at $85^{\circ} \mathrm{C}$ for 2 min with Reducing Agent (Life Technologies ${ }^{\mathrm{TM}}$ ) and equal quantities of total proteins $(20 \mu \mathrm{g} / \mathrm{lane})$ were resolved in NuPAGE® Novex® $16 \%$ Tris-Tricine precast gels (Life Technologies ${ }^{\mathrm{TM}}$ ). After electrophoresis, the proteins were transferred onto 0.2 $\mu \mathrm{M}$ PVDF membranes (Life Technologies ${ }^{\mathrm{TM}}$ ) for $1 \mathrm{~h}$ at $20^{\circ} \mathrm{C}$ using the liquid transfer system (Life Technologies ${ }^{\mathrm{TM}}$ ). Membranes were blocked with 5\% skimmed milk in TNT (15 mM Tris buffer $\mathrm{pH} 8.4,140 \mathrm{mM} \mathrm{NaCl}, 0.05 \%$ Tween-20) for $1 \mathrm{~h}$ at $20^{\circ} \mathrm{C}$. After washing three times, the membrane were incubated with APPCter-C17 rabbit antiserum diluted 1:4,000 in TNT overnight at $4^{\circ} \mathrm{C}$. APP-Cter-C17 was raised against the last 17 amino acids of the human APP sequence. ${ }^{45}$ To develop the immunoreaction, the blots were incubated with peroxidase-conjugated purified mouse monoclonal anti-goat/sheep IgG (Sigma A 9452, MAb clone GT-34), 1:10,000 in TNT-M, for $1 \mathrm{~h}$ at $20^{\circ} \mathrm{C}$, and developed with SuperSignal West Pico Chemiluminescent Substrate (Thermo Scientific). Membranes were scanned with LAS-4000 Mini Image System. AICD fragment (8 $\mathrm{kDa})$ and $\mathrm{CTF} \alpha(12 \mathrm{kDa})$ were detected. Images were obtained with a time exposure from 10 to 320s. Each image was opened with Adobe Photo Shop CS2 (version 9.0.2) computer program, a compose containing all WB bands was created for analysis. Bands quantification was performed by using Image $\mathrm{J} 1.37 \mathrm{v}$ computer program. Each band was transformed in a plot and the area under the curve was calculated. Results were expressed as arbitrary units of optical density. Membranes were then rinsed for $30 \mathrm{~min}$ at $20^{\circ} \mathrm{C}$ and reprobed with a goat polyclonal antibody against $\alpha$-Actin, GAPDH or Neuron Specific Enolase (1:1000; Santa Cruz Biotechnology). In vitro results are shown as the concentrations of compound able to double $\left(\mathrm{C}_{2}\right)$ or multiply 10 -fold $\left(\mathrm{C}_{10}\right)$ the quantity of AICD or CFT $\alpha$ quantified by Image J. 


\section{Secreted A $\beta_{1-38}, A \beta_{1-40}, A \beta_{1-42}$ and $\mathbf{s A P P} \alpha$ quantification}

Conditioned medium was used to determine the secreted $A \beta_{1-38}, A \beta_{1-40}$ and $A \beta_{1-42}$ concentrations, using the Human A $\beta(1-40)$ and $A \beta(1-38)$ Assay Kits (IBL) and the INNOTEST ${ }^{\mathrm{TM}}$ beta-Amyloid (1-42) ELISA Kit (Innogenetics). For sAPP $\alpha$ concentrations, the human sAPP $\alpha$ (highly sensitive) Assay Kit (IBL) was used according to the manufacturer's instructions. Each sample was loaded in duplicate onto a 96 well plate. Experiments were done in triplicate. Results expressed in $\mathrm{ng} / \mathrm{ml}$ were compared to control conditions arbitrarily given an average value of $100 \%$. Results are presented as $\mathrm{IC}_{50}$, the concentration able to decrease to $50 \%$ the basal quantity of secreted $\mathrm{A} \beta$ peptide 1-38, 1-40 and 1-42.

\section{Bioavailability properties}

Bioavailability-related profile was measured according to Lipinski et al. ${ }^{46}$ for aqueous solubility (PBS pH 7.4), and according to Sangster ${ }^{47}$ for partition coefficient (logD, n-octanol-PBS, $\mathrm{pH}$ 7.4) by CEREP (Paris, France).

\section{In vitro metabolic stability (mouse and human liver microsomes)}

Stock solutions of compounds were diluted in $100 \mathrm{mM}$ potassium phosphate buffer (KPi, $1 \mu \mathrm{M}$ final concentrations) $\mathrm{pH}=7.4$, and test compounds were then incubated for $60 \mathrm{~min}$ in an incubator shaker (Eppendorf) at $37^{\circ} \mathrm{C}$ and $1,400 \mathrm{rpm}$ with regenerating system (NADPH) and microsomal preparation (BD, final concentration $0.3 \mathrm{mg} / \mathrm{mL}$ in $\mathrm{KPi}$ buffer). Reactions were stopped with cold acetonitrile and Internal Standard (IS) CQ diphosphate was then added for further quantification 
(based upon Test compound/IS ratio area). Samples were mixed thoroughly and then centrifuged at 13,000 rpm for $10 \mathrm{~min}$. Supernatants were evaporated under vacuum (SpeedVac) at medium drying rate for $2 \mathrm{~h}$ and residues reconstituted in water $+0.1 \%$ TFA. Finally, $10 \mu \mathrm{L}$ volumes were injected into the LCMS system. Microsomal stability was calculated by comparison of area ratio of parent compounds at different times.

The LCMS system for the microsomal stability assay consisted of an Orbitrap Exactive instrument (Thermo) equipped with an electrospray ionization source used in positive mode $\left(\mathrm{M}+\mathrm{H}^{+}\right)$. The apparatus was managed with Xcalibur software. Tune parameters were set as: sheet gas flow rate at $70 \mathrm{~L} / \mathrm{min}$, aux gas flow rate at $20 \mathrm{~L} / \mathrm{min}$, spray voltage at $3.00 \mathrm{kV}$, capillary temperature at $275^{\circ} \mathrm{C}$, capillary voltage at $95 \mathrm{~V}$, tube lens voltage at $165 \mathrm{~V}$ and skimmer voltage at $36 \mathrm{~V}$. Tray temperature was set at $4^{\circ} \mathrm{C}$ and oven temperature at $30^{\circ} \mathrm{C}$. The analytical column was a $\mathrm{C} 18$ Hypersil Gold Thermo 50 × $2 \mathrm{~mm}, 1.9 \mu \mathrm{m}$ (Thermo). The mobile phase consisted of water $+0.05 \%$ TFA (A) and acetonitrile $+0.05 \%$ TFA (B). The linear gradient elution program was as follows: 0-100\% of B for $3.5 \mathrm{~min}$, followed by an isocratic hold at $100 \% \mathrm{~B}$ for $1 \mathrm{~min}$ and 2 min of reequilibration with $100 \%$ A for a total run of $6 \mathrm{~min}$ at a flow rate of $400 \mu \mathrm{L} / \mathrm{min}$. Due to the basicity of polyamines, good sensitivity was achieved using TFA in the mobile phase.

\section{In vivo acute treatment}

Female 4-month-old C57B16 mice were treated p.o. (gavage) with either carrier (water) or compound 29 as hydrochloride at $1 ; 3 ; 6 ; 12.5$ and $25 \mathrm{mg} / \mathrm{kg}$ (minimum number of animals per group = 6). After $24 \mathrm{~h}$, mice were sacrificed and the brain immediately removed to dissect the frontal cortex and hippocampus. Tissues were stored at $-80^{\circ} \mathrm{C}$ until western blot analysis. All experiments were carried out in accordance with the European Communities Council Directive of 
November 24th, 1986 (86/609/EEC) and the experimental protocols were approved by the local institutional animal research committee (Project number: CEEA-35014, agreement number 59350208).

\section{Statistics}

Statistical analysis was performed with Graph Pad Prism ${ }^{\circledR}$ software computer program. Analysis was performed using one-way ANOVA (F value), followed by a Fisher test. $p<0.05,0.01$ and 0.001 were considered statistically significant (respectively indicated $* * *$ and $* * *$ ). 


\title{
SUPPORTING INFORMATION
}

NMR spectra of compounds 35, 36 and $\mathbf{4 1}$ are available free of charge via the Internet at http://pubs.acs.org.

\begin{abstract}
ABBREVIATIONS
aa, amino acid; AD, Alzheimer's Disease; ADME, Absorption Distribution Metabolism Excretion; AICD, APP IntraCellular Domain; APP, Amyloid Precursor Protein; BBB, Blood-Brain Barrier; CTF, Carboxy-Terminal Fragment; CQ, Chloroquine; HCV, Hepatitis C Virus; LAR, Lysosome Accumulation Ratio; MTS, 3-(4,5-dimethylthiazol-2-yl)-5-(3-carboxymethoxyphenol)-2-(4-sulfo phenyl)-2H-tetrazolium salt.
\end{abstract}

\section{AUTHOR INFORMATION}

\section{Corresponding Author}

* Patricia Melnyk, EA4481, UFR Pharmacie, 3 rue du Pr Laguesse, BP83, 59006 Lille. Tel: 33

(0)3 20964949 - Fax: 33 (0)3 209649 13, e-mail: patricia.melnyk@ univ-lille2.fr

\section{Author Contributions}

Patricia Melnyk: Responsible for medicinal chemistry team, design of the study, and writing the manuscript.

Valérie Vingt-deux: Contributed to the development of the cell assay and obtained the result.

Stéphane Burlet: Choice of compounds, involved in scientific discussion. 
Sabiha Eddarkaoui: Contributed to the design of the assay and obtained the result.

Marie-Eve Grosjean: Contributed to the results.

Paul-Emmanuel Larchanché: Synthesis of new compounds.

Guillaume Hochart: Metabolic stability studies.

Christian Sergheraert: Design of the chemical library, involved in scientific discussion.

Cecilia Estrella: In vivo and in vitro study, analysis, involved in scientific discussion.

Matthieu Barrier: In vivo study, analysis, involved in scientific discussion.

Virginie Poix: In vivo study and CTF $\alpha$ WB.

Pauline Plancq: $\mathrm{A} \beta_{1-42}$ and sAPP $\alpha$ ELISA.

Cécile Lannoo: $\mathrm{CC}_{50}$ determination, $\mathrm{AICD}$ and $\mathrm{CTF} \alpha \mathrm{WB}$.

Malika Hamdane: developed and characterized the cell model.

André Delacourte: contributed to the design of the study, involved in scientific discussions.

Philippe Verwaerde: contributed to the design of the study, involved in scientific discussions

Luc Buée: contributed to the design of the study.

Nicolas Sergeant: responsible for the design of the study, wrote the manuscript.

All authors have approved the final version of the manuscript.

\section{Funding Sources}


This work was supported by the University of Lille 2, CNRS and Inserm. Grants were obtained from FEDER, OSEO and ANR.

\section{ACKNOWLEDGMENT}

We express our thanks to Emmanuelle Boll and Alexandre Barras for their contributions to organic synthesis and analysis, and to Nathalie Duhal and Dr Mostafa Kouach, CUMA, for help with the LCMS experiment.

The $300 \mathrm{MHz}$ NMR facilities were funded by the Région Nord-Pas de Calais (France), the Ministère de la Jeunesse, de l'Education Nationale et de la Recherche (MJENR) and the Fonds Européens de Développement Régional (FEDER).

\section{REFERENCES}

1. Vodicka, P., Lim, J., Williams, D.T., Kegel, K.B., Chase, K., Park, H., Marchionini, D., Wilkinson, S., Mead, T., Birch, H., Yates, D., Lyons, K., Dominguez, C., Beconi, M., Yue, Z., Aronin, N., DiFiglia, M. (2014) Assessment of chloroquine treatment for modulating autophagy flux in brain of WT and HD mice. J. Huntingtons Dis. 3, 159-74.

2. Korth, C., May, B. C. H., Cohen, F. E., Prusiner, S. B. (2001) Acridine and phenothiazine derivatives as pharmacotherapeutics for prion disease. Proc. Natl. Acad. Sci. USA 98, 9836-9841.

3. Doh-ura, K., Iwaki, T., Caughey, B. (2000) Lysosomotropic agents and cysteine protease inhibitors inhibit scrapie-associated prion protein accumulation. J. Virol. 74, 4894-4897. 
4. Kocisko, D. A., Baron, G. S., Rubenstein, R., Chen, J., Kuizon, S. et al. (2003) New inhibitors of scrapie-associated prion protein formation in a library of 2000 drugs and natural products. $J$. Virol. 77, 10288-10294.

5. Klingenstein, R., Melnyk, P., Leliveld, R. S., Ryckebusch, A., Korth, C. (2006) Similar Structure Activity Relationships of Quinoline Derivatives for antiprion and antimalarial effects. $J$. Med. Chem. 49, 5300-5308.

6. Ashfaq, U.A., Javed, T., Rehman, S., Nawaz, Z., Riazuddin, S. (2011) Lysosomotropic agents as HCV entry inhibitors. Virol. J. 8, 163-168.

7. Blanchard, E., Belouzard, S., Goueslain, L., Wakita, T., Dubuisson, J., Wychowski, C., Rouillé, Y. (2006) Hepatitis C virus entry depends on clathrin-mediated endocytosis. J. Virol. 80, 6964-72.

8. Vasquez-Martin, A., Lopez-Bonetc, E., Cuti, S., Oliveras-Ferraros, C., Del Barco, S., MartinCastillo, B., Menendez, J.A. (2011) Repositioning chloroquine and metformin to eliminate cancer stem cell traits in pre-malignant lesions. Drug Resist. Update 14, 212-223.

9. Mahoney, E., Maddocks, K., Flynn, J., Jones, J., Cole, S.L., Zhang, X., Byrd, J.C., Johnson, A.J. (2013) Identification of endoplasmic reticulum stress-inducing agents by antagonizing autophagy : a new potential strategy for identification of anti-cancer therapeutics in b-cell malignancies. Leuk. Lymphoma 54, 2685-92.

10. Costedoat-Chalumeau, N., Leroux, G., Piette, J.-P., Amoura, Z. (2010) Why all systemic lupus erythematosus patients should be given hydroxychloroquine treatment? Joint Bone Spine 77, 4-5. 
11. Suarez-Almazor, M.E., Belseck, E., Shea, B., Homik, J., Wells, G., Tugwell, P. (2010) Antimalarials for treating rheumatoid arthritis. Cochrane Database Syst. Rev. 4, CD000959.

12. Ryckebusch, A., Deprez-Poulain, R., Maes, L., Debreu-Fontaine, M.-A., Mouray, E., Grellier, P., Sergheraert, C. (2003) Synthesis and in Vitro and in Vivo Antimalarial Activity of N1-(7-Chloro-4-quinolyl)-1,4-bis(3-aminopropyl)piperazine Derivatives. J. Med. Chem. 46, 542557.

13. Ryckebusch, A., Deprez-Poulain, R., Debreu-Fontaine, M.-A., Vandaele, R., Mouray, E., Grellier, P., Sergheraert, C. (2003) Synthesis and Antimalarial Evaluation of New 1,4-bis(3aminopropyl)piperazine Derivatives. Bioorg. Med. Chem. Lett. 13, 3783-3787.

14. Bonnet, B., Soullez, D., Girault, S., Maes, L., Landry, V., Davioud-Charvet, E., Sergheraert, C. (2000) Trypanothione Reductase Inhibition/Trypanocidal Activity Relationships in a 1,4-Bis(3aminopropyl)piperazine Series. Bioorg. Med. Chem. 8, 95-103.

15. Yin, R.H., Tan, L., Jiang, T., Yu, J.T. (2014) Prion-like Mechanisms in Alzheimer's Disease. Curr. Alzheimer Res. 11, 755-64.

16. Vingtdeux, V., Sergeant, N., Buee, L. (2012) Potential contribution of exosomes to the prionlike propagation of lesions in Alzheimer's disease. Front. Physiol. 3, 229-250.

17. Vingtdeux, V., Hamdane, M., Loyens, A., Gelé, P., Drobecq, H., Bégard, S., Galas, M.-C., Delacourte, A., Beauvillain, J.-C., Buée, L., Sergeant, N. (2007) Alkalizing drugs induce accumulation of amyloid precursor protein by-products in luminal vesicles of multivesicular bodies. J. Biol. Chem. 282, 18197-18205. 
18. Kummer, M.P., Heneka, M.T. (2014) Truncated and modified amyloid-beta species. Alzheimers Res. Ther. 6, 28-36.

19. Yuyama, K., Yamamoto, N., Yanagisawa, K. (2006) Chloroquine-induced endocytic pathway abnormalities: Cellular model of GM1 ganglioside-induced Abeta fibrillogenesis in Alzheimer's disease. FEBS Lett. 580, 6972-6.

20. Bendiske, J., Bahr, B.A. (2003) Lysosomal activation is a compensatory response against protein accumulation and associated synaptopathogenesis--an approach for slowing Alzheimer disease? J. Neuropathol. Exp. Neurol. 62, 451-63.

21. De Strooper, B. (2010) Proteases and proteolysis in Alzheimer disease: a multifactorial view on the disease process. Physiol. Rev. 90, 465-494

22. Vingtdeux, V., Marambaud, P. (2012) Identification and biology of $\alpha$-secretase. $J$. Neurochem. 120 (Suppl 1), 34-45.

23. Pardossi-Piquard, R., Checler, F. (2012) The physiology of the $\beta$-amyloid precursor protein intracellular domain AICD. J. Neurochem. 120 (Suppl 1), 109-24.

24. Takami, M., Nagashima, Y., Sano, Y., Ishihara, S., Morishima-Kawashima, M., Funamoto, S., Ihara, Y. (2009) Gamma-Secretase: successive tripeptide and tetrapeptide release from the transmembrane domain of beta-carboxyl terminal fragment. J. Neurosci. 29, 13042-52.

25. Karran, E., Mercken, M., de Strooper, B.D. (2011) The amyloid cascade hypothesis for Alzheimer's Disease: an appraisal for the development of therapeutics. Nat. Rev. Drug Discov. 10, 698-712. 
26. Matsumura, N., Takami, M., Okochi, M., Wada-Kakuda, S., Fujiwara, H., Tagami, S., Funamoto, S., Ihara, Y. Morishima-Kawashima, M. (2014) Gamma-Secretase Associated with Lipid Rafts: Multiple Interactive Pathways in The Stepwise Processing of Beta-Carboxyl-terminal Fragment. J. Biol. Chem. 289, 5109-21.

27. Yan, R., Vassar, R. (2014) Targeting the beta secretase BACE1 for Alzheimer's disease therapy. Lancet Neurol. 13, 319-29.

28. Hall, A., Patel, T.R. (2014) Gamma-Secretase modulators: current status and future directions. Prog. Med. Chem. 53, 101-45.

29. Strömberg, K., Eketjäll, S., Georgievska, B., Tunblad, K., Eliason, K., Olsson, F., Radesäter, A.C., Klintenberg, R., Arvidsson, P.I., von Berg, S., Fälting, J., Cowburn, R.F., Dabrowski, M. (2015) Combining an amyloid-beta $(\mathrm{A} \beta)$ cleaving enzyme inhibitor with a $\gamma$-secretase modulator results in an additive reduction of $\mathrm{A} \beta$ production. FEBS J. 282, 65-73.

30. Vingtdeux, V., Hamdane, M., Bégard, S., Loyens, A., Delacourte, A., Beauvillain, J.-C., Buée, L., Marambaud, P., Sergeant, N. (2007) Intracellular pH regulates amyloid precursor protein intracellular domain accumulation. Neurobiol. Dis. 25, 686-696.

31. Tam, J.H., Seah, C., Pasternak, S.H. (2014) The Amyloid Precursor Protein is rapidly transported from the Golgi apparatus to the lysosome and where it is processed into beta-amyloid. Mol. Brain. 7, 54-71.

32. Melnyk, P., Sergeant, N., Buée, L., Delacourte, A. Use of 1,4-bis(3-aminoalkyl) piperazine derivatives in the treatment of neurodegenerative diseases. WO 2006/ 051489. 
33. Vingtdeux, V., Hamdane, M., Gompel, M., Bégard, S., Drobecq, H., Ghestem, A., Grosjean, M.-E., Kostanjevecki, V., Grognet, P., Vanmechelen, E., Buée, L., Delacourte, A., Sergeant, N. (2005) Phosphorylation of amyloid precursor carboxy-terminal fragments enhances their processing by a gamma-secretase-dependent mechanism. Neurobiol. Dis. 20, 625-637.

34. Lysosome Accumulation Ratios (LAR) was calculated in silico using the following equation:

$\mathrm{LAR}=\frac{1+\sum_{\mathrm{n}=1}^{4} \sum_{\mathrm{i}=1}^{\mathrm{n}} 10^{\mathrm{pKai}-\mathrm{pHL}}}{1+\sum_{\mathrm{n}=1}^{4} \sum_{\mathrm{i}=1}^{\mathrm{n}} 10^{\mathrm{pKai}-\mathrm{pH} 0}}$

Where: $\mathrm{pH}_{\mathrm{L}}$ is $\mathrm{pH}$ inside the lysosome (assumed to be $\mathrm{pH}$ 5.0) and $\mathrm{pHo}$ in the cytosol (assumed to be $\mathrm{pH}$ 7.4).

This equation is a derivation of the Henderson-Hasselbach equation, based on predicted values of drug $\mathrm{pKa}$ according to previous work of Hawley et al. ${ }^{35}$ Values of $\mathrm{pKa}$ were calculated using ACD/pKa DB software from Advanced Chemistry Development Inc., Toronto, Canada.

35. Hawley, S. R., Bray, P. G., O'Neill, P. M., Park, B. K., Ward, S. A. (1996) The role of drug accumulation in 4-aminoquinoline antimalarial potency. The influence of structural substitution and physicochemical properties. Biochem. Pharmacol. 52, 723-733.

36. Chasseigneaux, S., Allinquant, B. (2012) Functions of A $\beta$, sAPP $\alpha$ and sAPP $\beta$ : similarities and differences. J. Neurochem. 120, 99-108.

37. Ryckebusch, A., Deprez-Poulain, R., Debreu-Fontaine, M.-A., Vandaele, R., Mouray, E., Grellier, P., Sergheraert, C. (2002) Parallel Synthesis and Antimalarial Activity of a Sulfonamide Library. Bioorg. Med. Chem. Lett. 12, 2595-2598. 
38. Belyaev, N.D., Kellett, K.A., Beckett, C., Makova, N.Z., Revett, T.J., Nalivaeva, N.N., Hooper, N.M., Turner, A.J. (2010) The Transcriptionally Active Amyloid Precursor Protein (APP) Intracellular Domain Is Preferentially Produced from the 695 Isoform of APP in a beta-Secretasedependent Pathway. J. Biol. Chem. 285, 41443-41454.

39. Asai, M., Yagishita, S., Iwata, N., Saido, T.C., Ishiura, S., Maruyama, K. (2011) An alternative metabolic pathway of amyloid precursor protein C-terminal fragments via cathepsin B in a human neuroglioma model. FASEB J. 25, 3720-3730.

40. Vorobyeva, A.G., Lee, R., Miller, S., Longen, C., Sharoni, M., Kandelwal, P.J., Kim, F.J., Marenda, D.R., Saunders, A.J. (2014) Cyclopamine Modulates $\gamma$-Secretase-mediated Cleavage of Amyloid Precursor Protein by Altering Its Subcellular Trafficking and Lysosomal Degradation. $J$. Biol. Chem. 289, 33258-33274.

41. Goodger, Z. V., Rajendran, L., Trutzel, A. (2009) Nuclear signaling by the APP intracellular domain occurs predominantly through the amyloidogenic processing pathway. J. Cell Sci. 122, 3703-14.

42. Ghosal, K., Vogt, D.L., Liang, M., Shen, Y., Lamb, B.T., Pimplikar, S.W. (2009) Alzheimer's disease-like pathological features in transgenic mice expressing the APP intracellular domain. Proc. Natl. Acad. USA 106 (43), 18367-72.

43. Ghosal, K., Pimplikar, S.W. (2011) Aging and exitotxic stress exacerbate neural circuit reorganization in amyloid precursor protein intracellular domain transgenic mice. Neurobiol. Aging 32 (12), 2320, e1-9. 
44. Ohkawara, T., Nagase, H., Koh, C.-S., Nakayama, K. (2011) The amyloid precursor protein intracellular domain alters gene expression and induces neuron-specific apoptosis. Gene 475, $1-$ 9.

45. Sergeant, N., David, J.P., Champain, D., Ghestem, A., Wattez, A., Delacourte, A. (2002) Progressive decrease of amyloid precursor protein carboxy terminal fragments (APP-CTFs), associated with tau pathology stages, in Alzheimer's disease. J. Neurochem. 81 (4), 663-672.

46. Lipinski, C.A., Lombardo, F., Dominy, B.W., Feeney, P.J. (2001) Experimental and computational approaches to estimate solubility and permeability in drug discovery and development settings. Adv. Drug Deliv. Rev. 46, 3-26.

47. Sangster, J. (1997). Octanol-Water Partition Coefficients: Fundamentals and Physical Chemistry. Wiley Series in Solution Chemistry, Vol. 2, John Wiley and Sons, Chichester. 


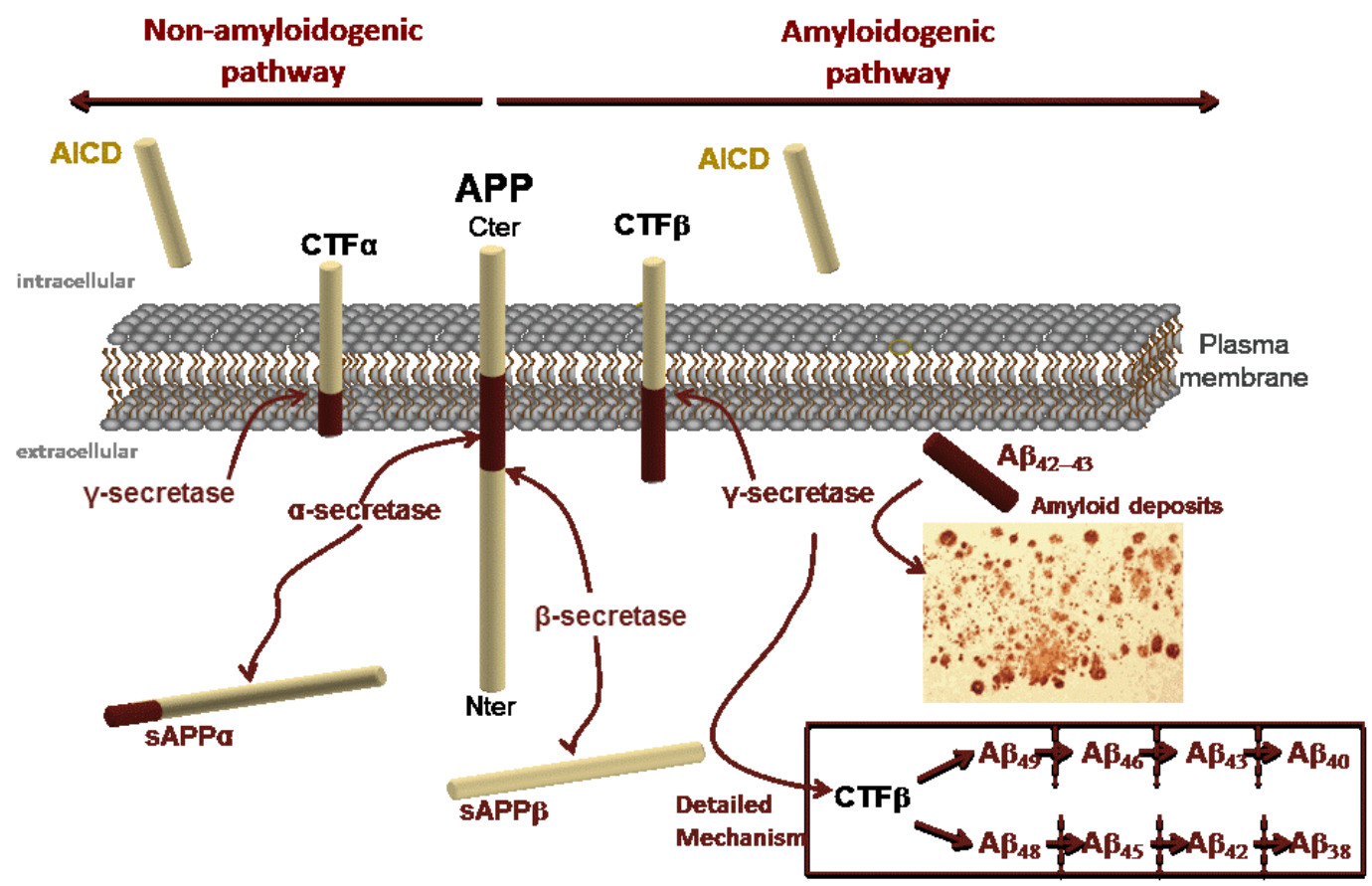

Figure 1. Amyloid Precursor Protein (APP) metabolism (adapted from Vingtdeux et al. ${ }^{16}$ ) 


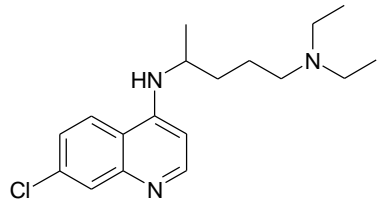

CQ

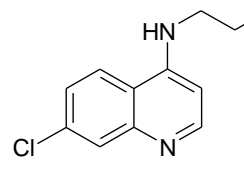

R3
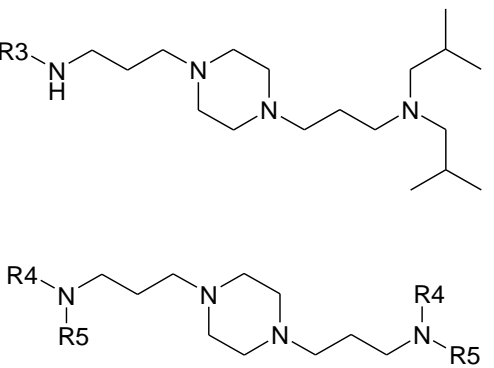

\section{Series I}

1-8 : R1=H, R2=COAr, COR 9-16: $\mathrm{R} 1=\mathrm{H}, \mathrm{R} 2=$ benzyl, alkyl

17-24: $\mathrm{R} 1=\mathrm{R} 2=$ benzyl, alkyl

25-26: NR1R2= pyrrolinyl, piperidinyl

\section{Series II}

27-32: R3=heteroaryl

33-37: R3=benzyl

\section{Series III}

38-46: R4=H, R5=H, benzyl, alkyl 47: $\mathrm{R} 4=\mathrm{R} 5=\mathrm{iBu}$

Figure 2. Chloroquine (CQ) and piperazine-derived compounds (Series I, II and III) 

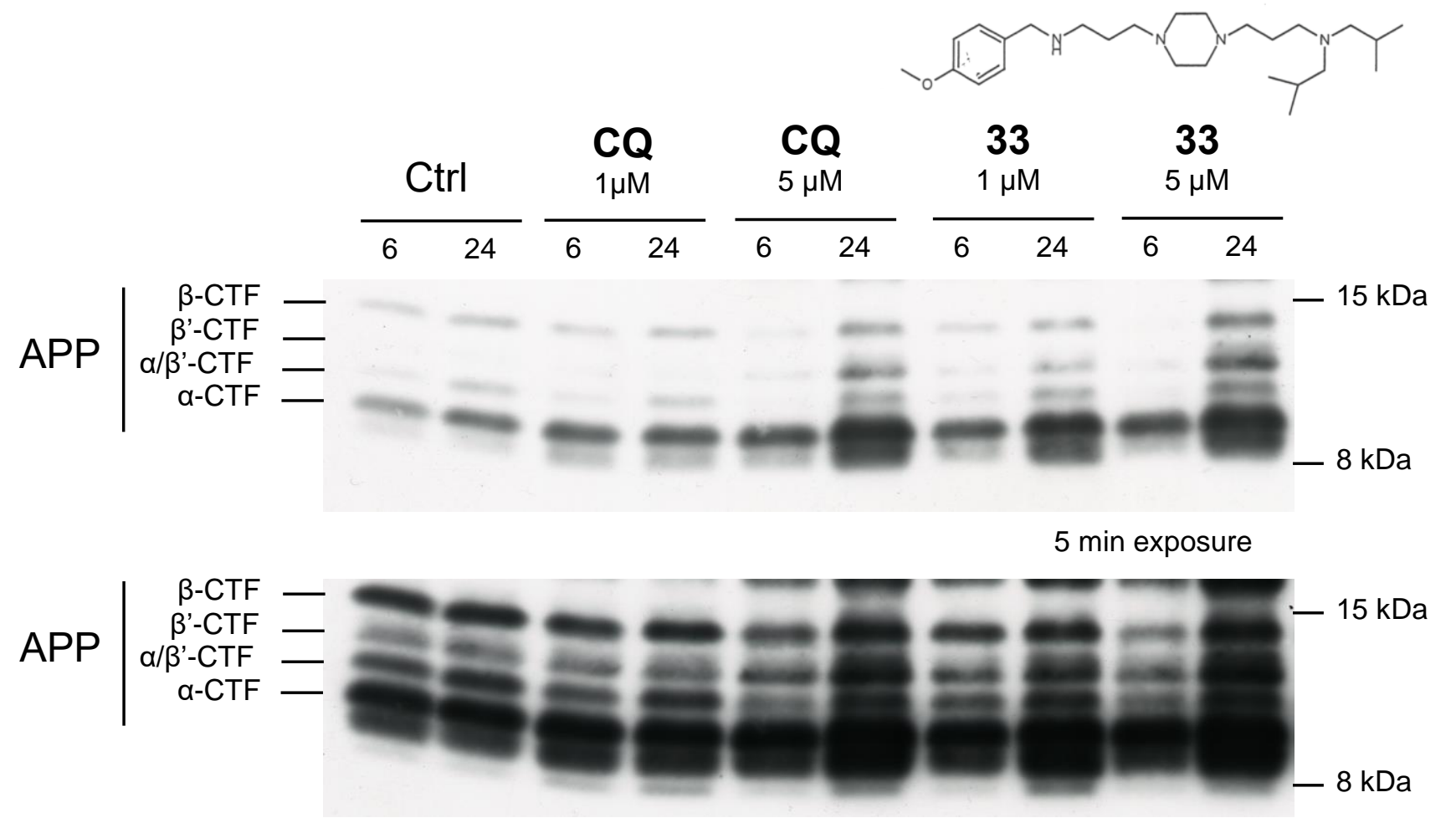

30 min exposure

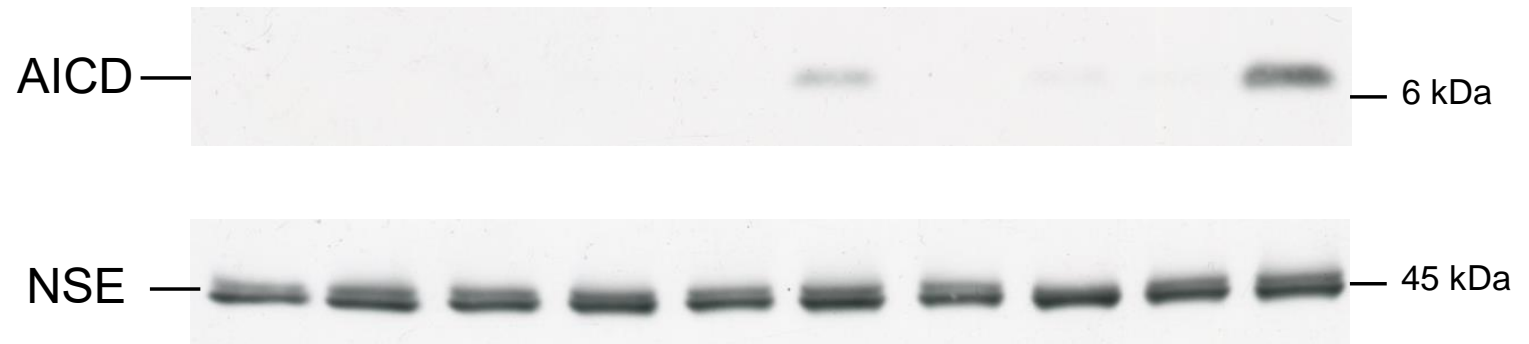

Figure 3: Effect of CQ-derivatives on APP metabolism.

SY5Y-APP wt were treated or not (Control condition : Ctrl) with 1 or $5 \mu \mathrm{M}$ of compound $\mathbf{3 3}$ (the structure is represented) and compared to the effect of chloroquine (CQ) at the same doses. After 6 or 24 hours of treatment, protein cell lysates were separated on 1D tris-tricine gels and APP metabolites, including APP-CTFs and AICD were detected with the APP-Cter-C17 antisera against the last 17 aa of the APP protein sequence. Apparent molecular weights are indicated on the right and were determined using the Novex ${ }^{\circledR}$ Sharp Pre-stained Protein Standard (3.5 to 260 $\mathrm{kDa})$. The $5 \mathrm{~min}$ exposure is used to quantify the amount of APP-CTFs whereas the $30 \mathrm{~min}$ exposure is used to visualize and quantify AICD. APP-CTFs released from the $\beta$ - ( $\beta$-CTF and $\beta$ '$\mathrm{CTF})$ or $\alpha$ - cleavage $(\alpha-\mathrm{CTF})$ are indicated on the left. Membranes were incubated with an anti neuron specific enolase (NSE) and used as loading control. Western-blot bands were quantified and results are reported on tables. 
A: Frontal Cortex

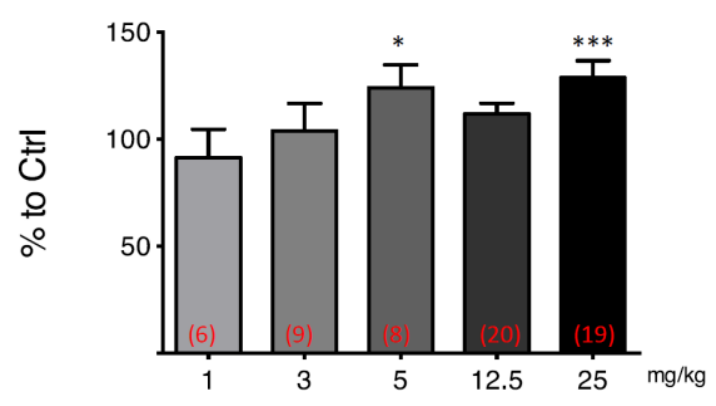

B: Hippocampus

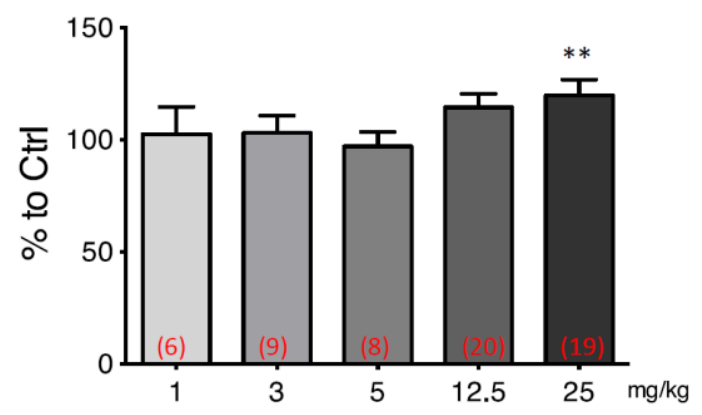

Figure 4. In vivo evaluation of compound 29.

C57B16 females were treated with compound 29 (as hydrochloride) for 24h. Semiquantitative levels of CTF $\alpha$ in frontal cortex (A) and hippocampus (B) after western blot; One-way ANOVA and Fisher test $* \mathrm{p}<0.05 ; * * \mathrm{p}<0.01$ and $* * * \mathrm{p}<0.001$, compared to control $(\mathrm{Ctl})$. The number of animals per group is indicated in parentheses. Results show the mean \pm SEM. 

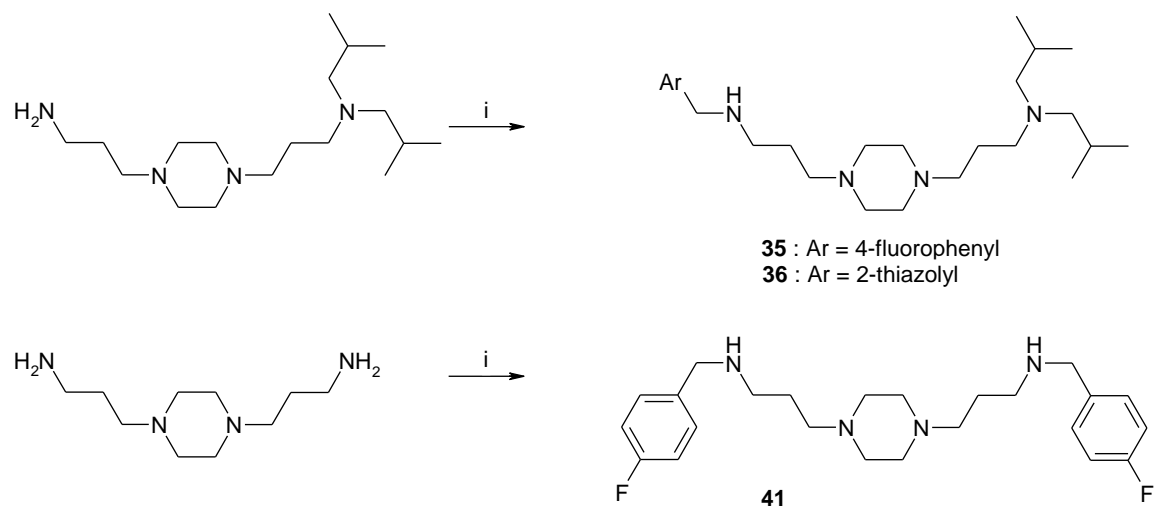

Reactants: (i) $\mathrm{ArCHO}, \mathrm{NaBH}_{4}, \mathrm{EtOH}, \mathrm{rt}$

Scheme 1. Synthesis of benzyl derivatives 35,36 and $\mathbf{4 1 .}$ 
Table 1. In vitro evaluation of compounds from Series I on SY5Y-APP ${ }^{\mathrm{WT}}$ cells

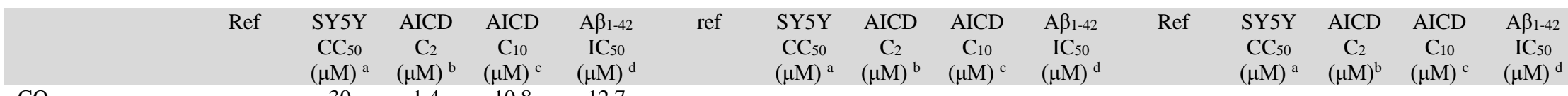

Quinacrine

$\begin{array}{lrrr}30 & 1.4 & 10.8 & 12.7\end{array}$

$(\mu \mathrm{M})^{\mathrm{a}} \quad(\mu \mathrm{M})^{\mathrm{b}} \quad(\mu \mathrm{M})^{\mathrm{c}} \quad(\mu \mathrm{M})^{\mathrm{d}}$

$\begin{array}{llll}5 & 1.0 & >5 & >5\end{array}$

$\mathbf{R}$
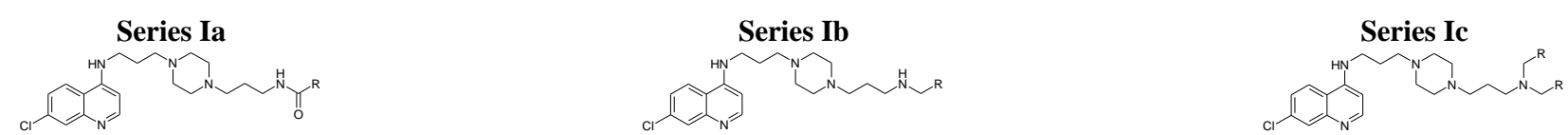

phenyl

157

$$
2.0 \quad 16.9
$$

10.3

\section{9}

$<5$

4-methoxyphenyl

26

4-chlorophenyl

31

4-nitrophenyl

417

methyl

$t$-butyl

cyclopropyl

$i$-propyl

$5>100$

$1.3 \quad 36.0$

10.8

$10 \quad 1.0$

17

18

$19 \quad 1.0$

$\begin{array}{llllll}2.1 & 13.9 & 9.6 & \mathbf{1 1} & 1.0\end{array}$

1.0

$12 \quad 17$

$20 \quad 3.0$

$\begin{array}{lllll}6 & 33 & 2.1 & 9.0 & 11.3\end{array}$

13

$\begin{array}{llll}48 & 1.4 & 19.3 & >10\end{array}$

14

27

$0.8 \quad 10.1$

15

60

pyrrolidinyl

piperidinyl

Mean values ce $50 \%$ of cell death after $24 \mathrm{~h}$ treatment; ${ }^{\mathrm{b}}$ Concentration doubling the quantity of AICD; ${ }^{\mathrm{c}}$ Concentration increasing the quantity of AICDs generated 10 -fold; ${ }^{\mathrm{d}}$ Concentration decreasing the secretion of $\mathrm{A} \beta$ by $50 \%$. 
Table 2. In vitro evaluation of compounds of Series II on SY5Y cells

\begin{tabular}{|c|c|c|c|c|c|c|c|c|c|c|c|}
\hline & Ref & SY5Y & AICD & AICD & $A \beta_{1-42}$ & & Ref & SY5Y & AICD & AICD & $A \beta_{1-42}$ \\
\hline & & $\begin{array}{l}\mathrm{CC}_{50} \\
(\mu \mathrm{M})^{\mathrm{a}}\end{array}$ & $\begin{array}{c}\mathrm{C}_{2} \\
(\mu \mathrm{M})^{\mathrm{b}}\end{array}$ & $\begin{array}{c}\mathrm{C}_{10} \\
(\mu \mathrm{M})^{\mathrm{c}}\end{array}$ & $\begin{array}{l}\mathrm{IC}_{50} \\
(\mu \mathrm{M})^{\mathrm{d}}\end{array}$ & & & $\begin{array}{l}\mathrm{CC}_{50} \\
(\mu \mathrm{M})^{\mathrm{a}}\end{array}$ & $\begin{array}{c}\mathrm{C}_{2} \\
(\mu \mathrm{M})^{\mathrm{b}}\end{array}$ & $\begin{array}{c}\mathrm{C}_{10} \\
(\mu \mathrm{M})^{\mathrm{c}}\end{array}$ & $\begin{array}{l}\mathrm{IC}_{50} \\
(\mu \mathrm{M})^{\mathrm{d}}\end{array}$ \\
\hline CQ & & 30 & 1.4 & 10.8 & 12.7 & & & & & & \\
\hline $\mathbf{R}$ & & \multicolumn{3}{|c|}{ Series IIa } & & $\mathbf{R}$ & \multicolumn{5}{|c|}{ Series IIb } \\
\hline $\begin{array}{l}\text { 7-chloro-4- } \\
\text { quinolinyl }\end{array}$ & 24 & 5.3 & 0.4 & 2.7 & 1.0 & $\begin{array}{l}\text { 4- } \\
\text { methoxyphenyl }\end{array}$ & 33 & 82 & 1.5 & 10.5 & 1.0 \\
\hline $\begin{array}{l}\text { 6-chloro-2- } \\
\text { methoxyacridin- } \\
\text { 9-yl }\end{array}$ & 27 & $<5$ & $>5$ & nd & $>5$ & 4-chlorophenyl & 34 & 30 & 1.3 & 16 & 2.4 \\
\hline 2-benzoxazolyl & 28 & $>100$ & e & nd & $>10$ & 4-fluorophenyl & 35 & $>30$ & 2 & 9.5 & f \\
\hline $\begin{array}{l}2- \\
\text { benzimidazolyl }\end{array}$ & 29 & 30 & 0.8 & 3.0 & 1.5 & 2-thiazolyl & 36 & nd & $\mathrm{e}$ & $\mathrm{e}$ & $>10$ \\
\hline 2-pyrimidinyl & 30 & 30 & $>10$ & nd & $>10$ & 4-pyridinyl & 37 & $>100$ & 3 & 5 & $>10$ \\
\hline 2-pyrazinyl & 31 & 30 & 4.1 & nd & $>10$ & & & & & & \\
\hline 6-purinyl & 32 & $>60$ & $>10$ & nd & $>10$ & & & & & & \\
\hline
\end{tabular}

Mean values calculated on the basis of at least three independent experiments with less than $10 \%$ deviation; nd: not determined; ${ }^{\text {a }}$ compound concentration causing $50 \%$ of cell death after $24 \mathrm{~h}$ treatment; ${ }^{\mathrm{b}}$ Concentration doubling the quantity of AICD; ${ }^{\mathrm{c}}$ Concentration increasing the quantity of AICDs generated 10 -fold; ${ }^{\mathrm{d}}$ Concentration decreasing the secretion of $\mathrm{A} \beta$ by $50 \%$; ${ }^{\mathrm{e}}$ decrease in the quantity of AICDs; ${ }^{\mathrm{f}}$ increase in the quantity of $\mathrm{A} \beta$ at $5 \mu \mathrm{M}$. 
Table 3. In vitro evaluation of compounds of Series III on SY5Y cells

\begin{tabular}{|c|c|c|c|c|c|c|c|c|c|c|}
\hline & Ref & SY5Y & AICD & AICD & $A \beta_{1-42}$ & Ref & SY5Y & AICD & AICD & $A \beta_{1-42}$ \\
\hline & & $\begin{array}{l}\mathrm{CC}_{50} \\
(\mu \mathrm{M})^{\mathrm{a}}\end{array}$ & $\begin{array}{c}\mathrm{C}_{2} \\
(\mu \mathrm{M})^{\mathrm{b}}\end{array}$ & $\begin{array}{c}\mathrm{C}_{10} \\
(\mu \mathrm{M})^{\mathrm{c}}\end{array}$ & $\begin{array}{c}\mathrm{IC}_{50} \\
(\mu \mathrm{M})^{\mathrm{d}}\end{array}$ & & $\begin{array}{l}\mathrm{CC}_{50} \\
(\mu \mathrm{M})^{\mathrm{a}}\end{array}$ & $\begin{array}{c}\mathrm{C}_{2} \\
(\mu \mathrm{M})^{\mathrm{b}}\end{array}$ & $\begin{array}{c}\mathrm{C}_{10} \\
(\mu \mathrm{M})^{\mathrm{c}}\end{array}$ & $\begin{array}{c}\mathrm{IC}_{50} \\
(\mu \mathrm{M})^{\mathrm{d}}\end{array}$ \\
\hline CQ & & 30 & 1.4 & 10.8 & 12.7 & & & & & \\
\hline $\mathrm{R}$ & & & & & & & & & & \\
\hline $\mathrm{H}$ & 38 & 5 & $>5$ & nd & $>5$ & & & & & \\
\hline 4-methoxyphenyl & 39 & 10 & $>10$ & nd & $\mathrm{e}$ & & & & & \\
\hline 4-chlorophenyl & 40 & 5 & 0.5 & 5.0 & 3.1 & & & & & \\
\hline 4-fluorophenyl & 41 & 10 & 1.0 & $>10$ & 1.0 & & & & & \\
\hline $\begin{array}{l}\text { 3,4- } \\
\text { dimethoxyphenyl }\end{array}$ & 42 & 20 & $>20$ & nd & $\mathrm{e}$ & & & & & \\
\hline 4-quinolinyl & 43 & 15 & $>10$ & nd & e & & & & & \\
\hline 4-pyridinyl & 44 & $>30$ & $>10$ & nd & $\mathrm{e}$ & & & & & \\
\hline cyclopropyl & 45 & $>30$ & 13 & nd & $\mathrm{e}$ & & & & & \\
\hline$i$-propyl & 46 & $>30$ & $>10$ & nd & $\mathrm{e}$ & 47 & 20 & 3.7 & $>20$ & $>10$ \\
\hline
\end{tabular}

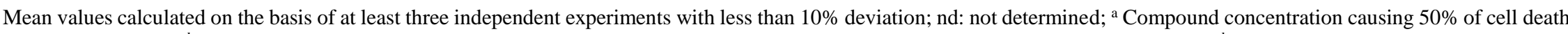
after $24 \mathrm{~h}$ treatment; ${ }^{\mathrm{b}}$ Concentration doubling the quantity of AICD; ${ }^{\mathrm{c}}$ Concentration increasing the quantity of AICDs generated 10 -fold; ${ }^{\mathrm{d}}$ Concentration decreasing the secretion of $\mathrm{A} \beta$ by $50 \%$; ${ }^{\mathrm{e}}$ increase in the quantity of $\mathrm{A} \beta$ at $5 \mu \mathrm{M}$. 
Table 4. In vitro impact of compounds $\mathbf{2 5 , 2 9}$ and 33 on APP metabolism (SY5Y cells)

$\begin{array}{lccccc}\text { Ref } & \text { CTF } \alpha & \mathrm{CTF} \alpha & \mathrm{A} \beta_{1-38} & \mathrm{~A} \beta_{1-40} & \mathrm{sAPP}^{\mathrm{d}} \\ \mathbf{C Q} & \mathrm{C}_{2}(\mu \mathrm{M})^{\mathrm{a}} & \mathrm{C}_{10}(\mu \mathrm{M})^{\mathrm{b}} & \mathrm{IC}_{50}(\mu \mathrm{M})^{\mathrm{c}} & \mathrm{IC}_{50}(\mu \mathrm{M})^{\mathrm{c}} & (10 \mu \mathrm{M}) \\ \mathbf{2 5} & 1.0 & \mathrm{nd} & 10.0 & 7.0 & +28 \% \\ \mathbf{2 9} & 0.2 & 11.2 & 5.0 & 9.1 & +30 \% \\ \mathbf{3 3} & 0.5 & >10 & 5.0 & 5.0 & +78 \% \\ & 6.7 & 28.4 & >10 & 5.1 & +55 \%\end{array}$

Mean values calculated on the basis of at least three independent experiments with less than $10 \%$ deviation; nd: not determined; a Concentration doubling the quantity of $\mathrm{CTF} \alpha{ }^{\mathrm{b}}{ }^{\mathrm{b}}$ Concentration increasing the quantity of $\mathrm{CTF} \alpha 10$-fold; ${ }^{\mathrm{c}}$ Concentration inhibiting $\mathrm{A} \beta$ secretion by $50 \%$; ${ }^{\mathrm{d}}$ increase in $\mathrm{SAPP} \alpha$ secretion at $10 \mu \mathrm{M}$. 
Table 5. Preliminary ADME results

\begin{tabular}{|c|c|c|c|c|}
\hline Ref & $\begin{array}{c}\text { Aqueous } \\
\text { solubility PBS pH } \\
7.4\end{array}$ & $\log \mathrm{D} p \mathrm{pH} 7.4$ & $\begin{array}{l}\text { Metabolic } \\
\text { stability }\end{array}$ & $\begin{array}{c}\text { Metabolic } \\
\text { stability }\end{array}$ \\
\hline & $(\mu \mathrm{M})$ & & $\mathrm{mLM}^{\mathrm{a}}$ & $\mathrm{hLM}^{\mathrm{b}}$ \\
\hline 25 & 227 & 0.1 & $100 \%$ & $100 \%$ \\
\hline 29 & 278 & 1.8 & $79 \%$ & $52 \%$ \\
\hline 33 & 200 & 1.2 & $30 \%$ & $27 \%$ \\
\hline
\end{tabular}

Mean values calculated on the basis of two independent experiments with less than $10 \%$ deviation; ${ }^{a}$ mLM: mouse liver microsomes; b hLM: human liver microsomes 
Graphic Table of Contents
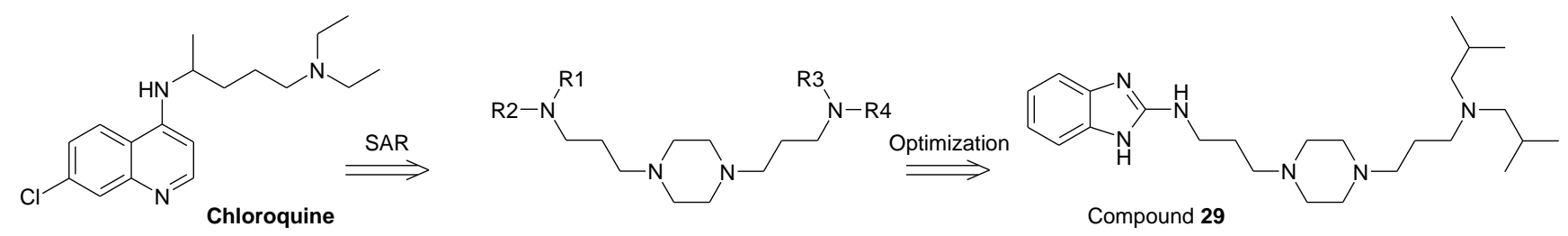